Leibniz-Institut für

Wirtschaftsforschung

Halle

Monetary Policy under the Microscope: Intra-bank

Transmission of Asset Purchase Programs of the ECB

Lisa Cycon

Michael Koetter

July 2015

No. 9

IWH-DISKUSSIONSPAPIERE 
Authors: $\quad$ Michael Koetter (corresponding author)

Halle Institute for Economic Research (IWH)

Department of Financial Markets

E-mail: Michael.Koetter@iwh-halle.de

Phone: +49 3457753820

Frankfurt School of Finance and Management

E-mail: m.koetter@fs.de

Phone: +4969154008446

Lisa Cycon

Frankfurt School of Finance \& Management

E-mail: L.Cycon@fs.de

The responsibility for discussion papers lies solely with the individual authors. The views expressed herein do not necessarily represent those of the IWH. The papers represent preliminary work and are circulated to encourage discussion with the authors. Citation of the discussion papers should account for their provisional character; a revised version may be available directly from the authors.

Comments and suggestions on the methods and results presented are welcome.

IWH Discussion Papers are indexed in RePEc-EconPapers and in ECONIS.

Editor:

Halle Institute for Economic Research (IWH) - Member of the Leibniz Association

Address: $\quad$ Kleine Maerkerstrasse 8, D-06108 Halle (Saale), Germany

Postal Address: P.O. Box 1103 61, D-06017 Halle (Saale), Germany

Phone: $\quad$ +49345775360

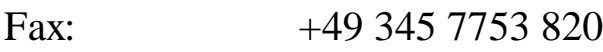

Internet: $\quad$ www.iwh-halle.de

ISSN 1860-5303(Print)

ISSN 2194-2188(Online) 


\title{
Monetary Policy under the Microscope: Intra-bank Transmission of Asset Purchase Programs of the ECB*
}

\begin{abstract}
englisch
With a unique loan portfolio maintained by a top-20 universal bank in Germany, this study tests whether unconventional monetary policy by the European Central Bank (ECB) reduced corporate borrowing costs. We decompose corporate lending rates into refinancing costs, as determined by money markets, and markups that the bank is able to charge its customers in regional markets. This decomposition reveals how banks transmit monetary policy within their organizations. To identify policy effects on loan rate components, we exploit the co-existence of eurozone-wide security purchase programs and regional fiscal policies at the district level. ECB purchase programs reduced refinancing costs significantly, even in an economy not specifically targeted for sovereign debt stress relief, but not loan rates themselves. However, asset purchases mitigated those loan price hikes due to additional credit demand stimulated by regional tax policy and enabled the bank to realize larger economic margins.
\end{abstract}

Keywords: unconventional monetary policy, asset purchase programs, ECB, interest rate channel, internal capital markets

JEL Classification: G01, G21, E42, E43, E52

* We are grateful for feedback received at the IWH Financial Markets Department workshop, Frankfurt School Finance Winterschool, the $4^{\text {th }}$ Financial Economics Workshop at the University of Mainz, the LAPE Financial Economics conference, the $5^{\text {th }}$ FEBS meetings, the $7^{\text {th }}$ International IFABS conference, and seminars at the EBRD, the Systemic Risk Centre at LSE, and the German Institute for Economics DIW. Comments from Claudia Buch, Cagatay Bircan, Stijn Claessens, Bill Francis, Ralph de Haas, Christa Hainz, Philip König, Iftekhar Hasan, Kose John, Nicola Limodio, Helmut Lütkepohl, Lukas Menkhoff, Phil Molyneux, Thomas Mosk, Katja Neugebauer, Zacharias Sautner, Larissa Schäfer, Isabel Schnabel, Sascha Steffen, Adalbert Winkler, Amine Tarazi, Michael Wedow, and Jean-Pierre Zigrand are highly appreciated. We are grateful for the provision of data by the bank. The expressed views and any remaining errors are our own. 


\section{Introduction}

Did asset purchase programs conducted by the European Central Bank (ECB) succeed in reducing the cost of corporate credit? Or did secondary market purchases merely subsidize banks' refinancing cost, and thus ultimately markups? We test if and how the Securities Market Programme (SMP) and the Covered Bond Purchase Programme (CBPP) reduced corporate loan rates after their launch in 2010. Based on a proprietary credit pricing sample provided by one of the 20 largest universal banks in the European Monetary Union, we observe corporate loan rates, which we decompose into the refinancing cost paid on the internal capital market and the markup charged to individual customers. This microscopic view allows us to identify the transmission of unconventional monetary policy (UMP) via banks' internal capital markets.

A crucial challenge when attempting to quantify loan rate effects is the need to separate increased credit supply due to expansionary monetary policy, whether conventional or not, from differences in loan demand by corporations. To test directly for pricing effects due to supply shocks, we observe whether the internal funding cost of individual loans respond significantly to changing intensities of asset purchases over time. Internal bank capital markets generally are not often observed (cf. Cremers et al., 2011). To our knowledge, this study is the first to observe actual refinancing rates charged internally by the treasury department to credit sales for individual loan contracts. With this information, we can test directly if UMP transmission fails or succeeds and why: because refinancing rates are irresponsive or because banks do not pass on lower funding costs to their corporate customers, as might be the case when they engage in liquidity hoarding (Benmelech and Bergman, 2012, Acharya and Merrouche, 2013) and increase their own margins.

We analyze the pricing of loans granted to a sample of approximately 13,000 corporations from the so-called German "Mittelstand". These firms are customers of a large universal bank operating throughout Germany that is systemically important and included in all stress tests conducted by the European Banking Authority (EBA) so far. The firms we focus on belong to the segment of small to medium-sized enterprises (SMEs) and, thus, rely less on capital markets but more on bank finance and contribute a major share to German GDP and employment. To distinguish differences in a firm's credit demand that might affect loan prices, potentially confounding the supply effects due to UMP, we exploit a feature of the German tax system. The authority to levy corporate taxes ("Gewerbesteuer") rests with municipality councils at the regional level. Each of the approximately 2,500 municipality councils in Germany determines this multiplier autonomously 
for one year. These taxes generate substantial aggregate revenues of approximately EUR 35 billion in 2012, which is equal in size to value added and income tax combined. Djankov et al. (2010) show that corporate investment demand, and thus demand for credit, depends inversely on firms' tax burden. Similar to Heider and Ljungqvist (2015), we use the spatial dispersion of fiscal policy to explain the cross-sectional variation in loan rates of corporate customers residing in different regional markets but that are exposed to an identical unorthodox monetary policy.

- Figure 1 around here -

Figure 1 shows the so-called "Hebesatz", which refers to the multiplier of corporations' taxable profits determined annually by each municipality. Taxable profits provide the basis to calculate the tax burden. We show average multipliers per district ("Kreise"), the next higher regional level at which we observe the location of bank customers. The map clearly illustrates the dispersion of tax multipliers across customer regions. Changes to the fiscal stance across these localities therefore support a clear identification of loan demand stimulus due to tax policy.

Fiscal policy should be exogenous to lending terms, for several reasons. First, we analyze a proprietary sample of loans to approximately 13,000 corporate customers that already reside in regional markets, not firms that might have been attracted to a region by its favorable tax conditions. The loans we consider also are either originated or rolled over at new terms. Thus, we gauge the pricing effects of UMP and regional fiscal policy (RFS) for the marginal loan. The vast majority of firms in our sample also are SME that only operate in one region and are unlikely to move their headquarters easily.

With this method, we can test for the effectiveness of unorthodox monetary policy by taking a detailed view of the internal transmission of monetary policy within a major German universal bank. We use a sample that provides borrower-specific information, detailed pricing data, and risk characteristics for each of the 40,116 individual loan facilities between August 2011 and December 2013. Our identification strategy exploits exogenous credit demand shocks due to local fiscal policy that affects borrowers differently across regions.

The interaction of fiscal policy and UMP is particularly useful for identification. Conventional monetary policy reached the zero-lower bound (ZLB), which impairs the ability of the interest rate channel to stimulate the economy 11 Fiscal policy can then serve as an important substitute to

\footnotetext{
${ }^{1}$ Policy rates were at a historical low of $0.05 \%$ in the European Monetary Union as of September 2014. Conventional expansionary monetary policy reduces nominal short-term rates, which reduces banks' refinancing cost and
} 


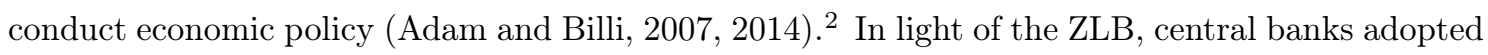
a wide range of instruments to steer short-term nominal rates (Gertler and Kiyotaki, 2010, Gertler and Karadi, 2011) and risk premia in general (Drechsler et al., 2014) ? $^{3}$ Among those instruments, we focus on the outright purchase of securities in secondary markets under the SMP and the second CBPP. Prior studies, such as Manganelli (2012) and Eser and Schwaab (2015), investigate possible price effects in bond markets and generally indicate enhanced market liquidity, lower sovereign yield spreads of EMU periphery countries, and a reduction of co-movement and jointdefault probabilities ${ }^{4}$ All of these factors enhance the funding conditions of banks Committee on the Global Financial System, 2011), such as by increasing the asset value of sovereign debt and lowering the associated capital requirements, increasing the value of pledgeable collateral, and creating easier capital market access. Consequently, banks' default risk and refinancing costs decrease, which should result in lower interest charged to customers.

But evidence about the real effects of these UMP measures remains scarce. Cross-country studies (Gambacorta et al., 2014) and evidence for the United States (Gilchrist et al. 2015) indicate output growth effects comparable to conventional interest rate changes. But UMP measures also have been assigned responsibility for a plethora of undesirable effects, such as liquidity hoarding (e.g. Benmelech and Bergman, 2012, Acharya and Merrouche, 2013), risky lending (e.g. Angeloni and Faia, 2013, Jiménez et al. 2014), regulatory arbitrage that exploits the preferential treatment of sovereign debt (e.g. Acharya and Steffen, 2015), and more generally interconnectedness among (insufficient) fiscal discipline of politicians, (in)stability among financial intermediaries, and monetary policy (Acharya et al. 2014). These concerns render our identification strategy based on tax policies particularly interesting, because Correia et al. (2013) show that fiscal policy is well equipped to overcome the adverse implications of UMP at the ZLB, such as liquidity traps (e.g. Benmelech and Bergman, 2012, Acharya and Merrouche, 2013).

thus should improve the provision of bank credit (e.g. Bernanke and Blinder, 1988, Bernanke and Gertler 1992 1995. Kiyotaki and Moore, 1997. Kashyap and Stein, 2000 Jiménez et al., 2012).

${ }^{2}$ For example Nakamura and Steinsson (2014) show that regionally dispersed government spending in the monetary union of the U.S. has a significantly positive impact on aggregate output.

${ }^{3}$ Early evidence on unconventional monetary policy in terms of exchange rate policy by Günter and Wieland (2003) highlights the limited effects of conventional monetary policy under ZLB circumstances in Japan during the mid-1990s. Iwata and $\mathrm{Wu}(2006)$ provide evidence, in the United States, that the effect of expansionary monetary policy at the ZLB on output is about half compared to a non-ZLB environment. Further examples of UMP measures include "forward guidance" (Gertler and Karadi 2015), targeted lending schemes, long-term lending to financial institutions (Ferrando et al. 2015), lenient collateral frameworks (Araújo et al., 2015) and more intensive use of government securities as collateral (Acharya and Merrouche, 2013. Fratzscher and Rieth 2015).

${ }^{4}$ See, for example, Lucas et al. (2010), Ghysels et al. (2014), Pelizzon et al. (2015), Falagiarda and Reitz (2015), De Pooter et al. (2012), Eser and Schwaab (2015), Manganelli (2012), and Doran et al. (2013). 
We find that unorthodox monetary policy measures, in the form of security purchases under the SMP and the CBBP schemes, reduced refinancing costs. A one standard deviation increase in the mean assets purchased reduces the average refinancing costs of a loan by 5 basis points. UMP has no significant direct effect on the interest margin and customer interest rates. But the differential effect of expansionary unorthodox monetary policy, given a fiscal stimulus in the region, actually reduces customer rates and the interest margins earned by the bank. Interest hikes in response to tax-induced demand shocks thus are mitigated by a commensurate expansionary credit supply shock, embodied in an unconventional monetary policy. The fiscal stimulus, in terms of reduced corporate tax multipliers exerts significantly positive effects on both customer rates and markups, as expected. Firms facing a fiscal stimulus in their district pay on average $0.45 \%$ more interest on their loans than firms without any or an opposite fiscal decision, equivalent to a markup of $16 \%$ on the average interest rate a firm pays.

We test the robustness of our findings using different combinations of fixed effects and an instrumental variable regression approach to scrutinize the identification of loan pricing terms due to unconventional monetary policy as opposed to effects resulting from regional differences in loan demand. To rule out that fiscal policy is driven by unobserved factors, we instrument it by three factors that drive fiscal policy: random aggregate demand shocks due to natural disasters, elections, and regional macroeconomic conditions. Furthermore, we investigate the type of unconventional monetary policy that is in place and show that our main results is not driven by alternative monetary policy measures conducted during the sample period. We add analyses regarding to which type of firms and through which loan products unconventional monetary policy transmitted.

Section 2 outlines the identification strategy we use, before we describe our data in Section 3. Section 4 discusses our results, and we conclude in Section 5 .

\section{Specification and identification}

\subsection{Specification}

The unit of analysis in our study is monthly loans $j$ from August 2011 to December 2013. For each firm $i=1, \ldots, 12,975$ located in district $d=1, \ldots 406$, we explain the variation in interest rates $r$ per loan in product category $k=1, \ldots, 4$ in month $t=1, \ldots, 29$, in response to the volume of outstanding $U M P$ measures and an indicator of regional fiscal stimulus RFS. This variable is equal to 1 if the district council lowered the tax multiplier relative to the preceding year. We use 
ordinary least squares (OLS) with fixed effects and robust standard errors unless noted otherwise to estimate:

$$
Y_{j d t}=\alpha_{i k}+\alpha_{d}+\alpha_{t}+\beta_{1} X_{i j d t}+\beta_{2} U M P+\beta_{3} R F S+\beta_{4}(U M P \times R F S)+\epsilon_{j d t} .
$$

The dependent variable $Y_{j d t}$ abbreviates the loan's interest rate and its components, and $X_{i j d t}$ is a vector of firm and facility traits per period. All variables are detailed in Table 12 and we describe the sampling and the data in greater detail in Section 3

We consider only new pricing choices by the bank, such that we include new and rolled over loans, but exclude outstanding loans, to identify the differential effects of monetary and fiscal policy on corporate interest rates. Whether a new pricing choice is made on existing loans depends on the contractually determined expiration date of interest rate fixation. The empirical challenge of this exercise is to separate the effects of loan demand and supply that determine loan rates.

Similar to Khwaja and Mian (2008), De Haas and Van Horen (2013), or Ferrando et al. (2015), we mitigate omitted variable bias and isolate the effects of regional fiscal policy and UMP by saturating the model with three vectors of fixed effects. First, district fixed effects gauge unobserved and persistent differences across German regions (e.g., East versus West Germany) that may codetermine loan demand and rates. Second, time fixed effects capture conventional monetary policy and business cycle fluctuations, which influence loan interest rates almost by construction. Third, we specify firm-product category fixed effect: 5 and thereby ensure a comparison of interest rates for comparable financial products across firms that reside in different regions. In addition, we control for facility- (e.g., regulatory capital charges), firm- (e.g., ratings), and district (e.g., unemployment) specific variables, as we detail subsequently.

The specification thus can explain differences in interest rates across different loans, per firm and loan category, in the cross-section, after accounting for time-invariant, district-specific factors that shift credit demand and for common cyclical variation over time. We test whether the remaining variation in interest rates can be attributed to the UMP as it interacts with regional differences in loan demand shocks through fiscal policy.

\footnotetext{
${ }^{5}$ The four categories are: money market loans, promotional loans ("Förderkredite"), investment loans, and leasing.
} 


\subsection{Unconventional monetary policy}

We assume that loan pricing and credit provisioning did not trigger the unconventional monetary policy, which would give rise to reverse causality concerns between SMP and CBPP 2 purchases and the bank's loan supply. In response to the European sovereign debt crisis, the European Central Bank (ECB) launched the SMP in May 2010 to buy sovereign bonds from five distressed EMU countries in secondary markets: Italy, Ireland, Spain, Portugal, and Greece (Manganelli, 2012, Eser and Schwaab, 2015). In November 2011, it followed up with the CBPP 2, extending the preceding CBPP 1, which ended in June 2010, to buy covered bonds with certain criteria from primary and secondary markets.

The variable $U M P$ in (1) refers to the outstanding volumes of securities purchased under the $S M P$ and $C B B P$ schemes. We obtain the data from the weekly financial statements of the ECB. Figure 2 shows the evolution of outstanding stocks during the sample period.

- Figure 2 around here -

Together, both programs absorbed around 220 billion Euros, almost $3 \%$ of the Eurozone gross domestic product. Reverse causality may pose an important concern in analyses of loan market conditions and bond pricing in supported markets, (e.g., Falagiarda and Reitz, 2015, Gambacorta et al. 2014). However, loan supply conditions in Germany, let alone those of an individual bank, are unlikely to trigger large-scale sovereign bond purchases on their own.

Both programs ended de facto after the president of the ECB, Mario Draghi, announced in July 2012 that "the ECB is ready to do whatever it takes to preserve the euro. And believe me, it will be enough" (Draghi, 2012). Outright monetary transactions were introduced to regulate further government bond purchases by the ECB. The last purchases under the SMP were conducted in February 2012, and under the CBPP, they lasted until October 2012. Thereafter, the outstanding volume of assets decreased gradually as bonds matured.

The bank was included in all three stress tests conducted in 2010, 2011, and 2014 by the EBA and is as such considered systemically relevant to the European banking system. These stress tests indicate existing exposures to southern European countries whose assets were the focus of the asset purchase programs that we analyze. Therefore, the bank's business choices should respond to the asset purchase programs of the ECB, either due to outright asset sales or due to asset valuation effects.

We use the time-varying magnitude of these two unconventional monetary policy measures to 
represent an exogenous credit supply shock to the German bank and its transmission to the cost of loans. This shock is uniform across the regions in which firms demanding credit reside. Therefore, we complement the time dimension of identification with cross-sectional differences across firms' districts.

\subsection{Regional taxes}

Akin to Heider and Ljungqvist (2015), we employ tax changes at the district level to establish the differential treatment of firms' credit demand. Specifically, we exploit regional corporate taxes ("Gewerbesteuer"), on which each municipality decides autonomously in each year. These taxes are an important source of regional governments' income. In 2012, municipalities received EUR 35.2 billion in corporate taxes, more than income taxes and sales taxes combined (i.e., totalling EUR 33.0 billion (Statistische Ämter des Bundes und der Länder (2014)). It is one of the five critical taxes in Germany, which together generated 83\% of national tax revenue in 2011.

Corporate taxes are set and collected at the municipality ("Gemeinde") level, which is nested in the district ("Kreis") level that we observe ${ }^{6}$ Corporate taxes are calculated on the basis of the corporations' earnings power, equivalent to revenue adjusted for certain allowances determined by local tax authorities. This calculation also provides the basis for calculating corporate taxes, that is, the product of earnings power and the corporate tax multiplier, as indicated in Figure 1. Corporations pay corporate taxes in the municipality in which they are headquartered. If commercial units are spread across multiple municipalities, the corporate tax is split according to employees' wages. Because we observe only the location of firms' headquarters, we include the tax rate of the district in which each headquarters is located.

In setting the tax multiplier, municipalities balance their desire to attract new ventures, by offering attractive fiscal conditions, against foregoing too much tax revenue by setting their tax rates too low. To avoid regional beggar-thy-neighbor policies, the corporate tax multiplier is subject to a legal floor of $200 \%$. To avoid correlation by construction, we only consider loans granted to existing client relationships that are either entirely new or rolled over at new pricing conditions. That is, we test for the cross-sectional differential effect in the bank's loan pricing choices between firms that are already present in the region but that demand credit under different fiscal regimes.

Like Heider and Ljungqvist (2015) we use tax changes rather than levels and measure a regional

\footnotetext{
${ }^{6}$ We average corporate tax multipliers per district to preserve confidentiality of the loan customer data.
} 
fiscal stimulus $R F S$ with an indicator variable equal to 1 if the district decreased its corporate tax rate compared with the previous year. We obtain annual corporate tax rates as averages per district from Regional Database Germany Statistisches Bundesamt Deutschland / Regionaldatenbank Deutschland (2014). Figure 3 shows maps of all districts to which we can allocate the banks' customers, whether the corporate tax multipliers increased, declined, or stayed constant.

- Figure 3 around here -

Declining corporate taxes trigger investments and should therefore increase loan demand by corporations facing a fiscal shock, relative to those in regions with constant or increased tax burdens 7 Fiscal stimuli over time and regions are dispersed, as shown in Figure 3

In summary, our identification relies on regional fiscal shocks that affect loan demand differently across regions, time, and unorthodox monetary policy, which differs in intensity over time. Together these shocks permit us to identify the individual effects of each policy as well as the interplay between centralized monetary policy measures that are the zero lower bound and autonomous fiscal policy at the regional level for loan pricing.

\section{Data}

\subsection{Sampling}

We observe all corporate loans granted by one of the 20 largest universal banks in Europe between August 2011 and December 2013. The sample covers corporate SMEs with turnover greater than EUR 2.5 million. Very large firms with a yearly return of more than EUR 500 million and stock-listed corporations are excluded from our dataset. We further exclude foreign borrowers, loans denominated in a foreign currency, and financial firms. For each firm, we observe when an individual loan is either originated anew or rolled over with new pricing terms. We cover four credit product groups: money market loans, promotional loans, investment loans, and leasing. We exclude evergreening loans and allow only fixed term lending. Multiple loans within a product category in the same month are combined, such that we average the interest rates and aggregate the volumes, such as risk-based capital and the like, as we discuss subsequently. In turn, we obtain an unbalanced sample of facilities per firm and loan category.

\footnotetext{
[ Heider and Ljungqvist (2015) emphasize the asymmetric response of the corporate capital structure to tax hikes or reductions. Therefore, using robustness checks, we check for the influence of tax hikes or the magnitude of tax changes relative to preceding levels per district.
} 
- Table 1 around here -

Table 1 presents the descriptive statistics for the final sample, and the variable definitions are in Table 12 The sample comprises 40,116 loans to 12,975 firms during 29 months between August 2011 and December 2013. Some firms receive multiple loans per category per month, but most have just one. This unbalanced sample contains 30,373 money market loans, 4,514 promotional bank loans, 4,306 investment loans, and 923 leasing loans. That is, the majority of loans imply short-term purposes. About one-quarter of all observations serve a dedicated, long-term investment purpose.

\subsection{Interest rates}

The top panel of Table 1 shows the dependent variables: charged customer interest rates, internal refinancing rates, and the bank markup. On average, SMEs pay an interest rate of $2.78 \%$. The data permit us to decompose this customer rate into two components that gauge intra-bank UMP transmission. The interest margin is the internal spread between refinancing costs and the interest rate, accounting for the borrower's risk, administrative expenses, the opportunity cost of capital, and a profit. Part of the margin covers the fixed costs for the loan-providing sales unit, such as costs to run its sales force. Finally, it is at the discretion of the relationship manager to set the interest rate margin, which averages $1.89 \%$ over all facilities during the sample period.

The refinancing rate is charged internally by the treasury division, which manages payment flows within the bank, balancing the asset and liability sides by ensuring sufficient funding and investing excess liquidity. Loan-granting business units must pay an internal compensation for the liquidity they need to originate customer loans. This mechanism ensures the efficient transformation of maturities and cash-flow amounts within the bank. The compensation cost is determined daily and differs across loans within months. It depends on the cash-flow structure of the facility, the risk of changing interest rates over the life of the loan, and the bank-specific liquidity risk to receive the funds on the market; it averaged 87 basis points in the entire sample. Counterparties in capital markets assess the financial institution's creditworthiness and adjust their pricing with a mark-up that remunerates them for any additional counterparty risk. Figure 4 illustrates the evolution of mean customer rates over time, as well as the relative composition of customer rates.

- Figure 4 around here -

Interest rates declined from about $3.7 \%$ in August 2011 to $2.6 \%$ in December 2013, remaining 
stable thereafter. The composition of interest rates changed considerably though. The refinancing component declined continuously from about $57 \%$ to $38 \%$ over the sample period. Margins in turn soared by about $40 \%$ during the observation period. The descriptive evidence therefore indicates that monetary policy succeeded in reducing funding pressure on banks, as reflected by reduced refinancing costs. The transmission to corporate lending rates through banks' internal capital markets is less obvious though. Identifying whether it reflects the extraction of rents due to market power or the absence of profitable and adequately risky investment projects requires additional information on borrowers' demand differences though. Therefore, we exploit regional differences in the fiscal stance faced by different borrowers to identify which effect dominates.

In the last three columns of table 1 we show the results of performing a difference-in-difference test on the mean of the dependent loan pricing variables as well as our explanatory variables. The interest rate and its variable part, the interest margin, are significantly different between firms which are exposed to a fiscal shock and those which are not. This relationship is removed after the period were asset purchase programs were mainly conducted and following the introduction of outright monetary transactions, $O M T$. During the latter period, facility level characteristics differ significantly between firms. What does not differ at all, are the mean characteristics of our sample firms over time and related to fiscal shocks showing that it is not a change in borrower characteristics over time that leads to changes in loan pricing. Therefore, we investigate the variation in the interest rate and its components controlling for facility and firm level information with respect to $U M P$ and $R F S$.

\subsection{Explanatory variables}

Beyond firm-credit category, district, and time fixed effects, we specify additional controls to explain the three interest rates in Table 1. We follow prior empirical studies that test theoretical models of interest margins (e.g. Ho and Saunder, 1981) 8 papers that also observe internal bank capital markets (e.g. Cremers et al., 2011), and studies of bank internal pricing procedures.

At the facility level, we specify four control variables that should affect customer rates and markups primarily. First, an indicator equals 1 if the customer has pledged collateral for the loan, which controls for the risk associated with its specific exposure. Second, we specify the size of

\footnotetext{
${ }^{8}$ This empirical literature stream is plagued though by the unobservability of interest rates, as noted by Saunders and Schumacher (2000), Maudos and Fernandez de Guevara (2004), Memmel (2011). Rates are often imputed from coarse revenue (expense) categories and associated interest-bearing assets (liabilities), then averaged across heterogenous samples of banks.
} 
the loan in terms of the risk-weighted asset, which also gauges the regulatory capital burden of the bank. Third, we specify the duration of the loan contract in months. Fourth, an indicator variable equals 1 if the loan was originated by a standardized procedure, which is only available to customers with good ratings and for small loan sizes.

Refinancing rates depend on financial market conditions and assessments by counterparties of the bank's risk 9 Therefore, we specify three additional variables, using market data pertaining to the day when the new loan started or the interest rate was determined for a rolled over loan. First, we specify the price of the five-year senior credit default swap, $C D S$, of the bank. Second, to capture the term structure of interest rates at the time a loan originated, we specify both short-term rates and the short-term spread, which is the difference from a very short-term rate in financial markets 10

At the firm level, we specify six controls. First, the internal rating by the bank of the firm at the time that the loan was issued gauges risk. Second, beyond facility-specific risk-weighted assets, we observe the amount of capital the bank holds, relative to the total exposure with the customer per month captured, or what we call capital lockup. Third, we gauge the scale of the customer relationship, and fourth, we measure its scope. Crosssell indicates whether the customer generates profits in a product category, other than through loans, in that year. Turnover large indicates if the firm's annual sales are greater than the sample median. Fifth, we specify profit to gauge the monthly result of the bank-firm relationship in thousands of Euro, as well as an indicator variable profitable, if the result is a profit rather than a loss.

\section{Results}

\subsection{Main result}

Table 2 shows the results when we regress the full set of fixed effects, control variables, and monetary and fiscal policy measures on the interest rate, interest margin, and refinancing rate 11 Unconventional monetary policy, $U M P$, comprises the weekly cumulative amount of securities

\footnotetext{
${ }^{9}$ Cremers et al. (2011) consider a network of independent branches that are profit centers and possess different negation power over interest rates charged for internal funding with treasury. In contrast, we consider a bank for which the treasury quotes refinancing costs that apply uniformly for all business units equally, irrespective of whether they are cost centers, profits centers, or other business units.

${ }^{10}$ For confidentiality, we do not report descriptive statistics of the $C D S$ spreads and label the term structure variables generically. We also specified various alternative long-term rates.

${ }^{11}$ Table 13 in the appendix shows the coefficient estimates for all control variables to explain the customer interest rate, the interest margin, and the refinancing rate. We do not report these estimates in the main results to conserve on space.
} 
purchased under the SMP and the CBPP 2 programs, respectively. The RFS indicator equals 1 if the district where a firm resides has reduced its corporate tax multiplier.

- Table 2 around here -

The first column shows the effect on customer interest rates charged. Customers borrowing in districts that lowered their corporate taxes incurred $0.450 \%$ higher interest rates than borrowers in districts where tax rates were not reduced. We attribute this direct effect of a fiscal stimulus to differences in the credit demand by SMEs, which are not explained by specific firm or credit category traits, cyclical demand factors captured by time fixed effects, or regional macro differences captured by the district fixed effects. The coefficient estimated for $U M P$ is negative but not statistically different from zero. Larger outstanding volumes of purchased securities therefore exert no direct effect on customer loan rates. The interaction term shows, however, that unconventional monetary policy mitigates the interest rate hike in response to a fiscal demand-side stimulus. A one standard deviation increase in unconventional monetary measures, conditional on a stimulating fiscal policy shock, reduces interest rates by $0.028 \%[12$ at the mean - a $6.2 \%$ reduction of the increase following a stimulating fiscal policy shock 13 Thus, our results suggest that asset purchase programs as monetary policy instruments alone did not succeed in reducing corporate loan rates per se. But they can be effective in mitigating demand-push effects on interest rates.

The second column shows evidence of a more direct channel through which monetary policy transmits to corporations' borrowing cost, namely by reducing the bank's refinancing rates. For this sample, we find indeed that the unorthodox monetary policy reduces the refinancing costs for this German bank. A one standard deviation increase in assets bought under the unconventional monetary policy measures decreases the average refinancing rate by $0.045 \%$, which is an approximately $5.2 \%$ decrease from the mean 14 This result is remarkable, in that we are documenting another effect of programs explicitly designed to alleviate funding pressure in EMU-peripheral countries; they also eased capital market conditions for financial institutions elsewhere. As can be

\footnotetext{
${ }^{12}$ Analogous to Table 1 we calculate the effect of a standard deviation of $U M P, 0.015: 0.015 \times-1.928=-0.029$. An increase in $U M P$ from the mean of 0.215 trillion EUR to 0.230 trillion EUR changes the interaction term from -0.415 to -0.443 , which corresponds to a delta of 0.028 . Thus, the interest rate differential between districts exposed to a regional fiscal shock, $R F S$, decreases - here from $(0.448-0.415=) 0.033$ to $(0.448-0.441=) 0.005 \%$. The delta of 0.028 corresponds to a $6.2 \%$ decrease from the initial interest rate increase of 0.450 due to a $R F S$

${ }^{13}$ Table 13 in the appendix further shows that interest rates are higher for more risky exposures, larger riskweighted assets, longer durations, profitable customer relationships, higher levels of short-term rates in money markets, and a steeper yield curve for very short and short segments.

${ }^{14}$ The standard deviation of $U M P$ is 0.015 . Increasing $U M P$ from its mean of 0.215 to 0.230 reduces the refinancing rate by $0.045(=0.015 \times-2.992)$. The mean of the refinancing rate, according to Table 1 , is 0.865 . Thus, reducing the refinancing rate to $0.820 \%$ corresponds to a reduction of $5.2 \%$.
} 
expected, regional fiscal policy in Germany had no effect on refinancing conditions. The very high explanatory power of this regression illustrates, and results in Table 13 confirm, that refinancing costs are almost solely determined by money market conditions, as captured by the yield curve and the term structure of the loan. In summary, whereas asset purchase programs reduced the refinancing costs of banks, this supply-driven reduction did not translate into a statically significant reduction in the interest rates passed on to SME customers through internal capital markets.

The results in column 3 for the interest margin confirm the effects documented for customer loan rates. A loan demand shock induced by fiscal stimulus results in a significant increase of interest margins, on the order of $0.450 \% 15$ Similar to customer rates, this price push is mitigated by expansionary $U M P$ measures ${ }^{16}$ The parallel effects for the interest rate and interest margin indicate that only the variable part of the interest rates is sensitive to demand shocks (e.g., through loan officers' discretion).

\subsection{Identification}

\subsubsection{Alternative fixed effects}

Table 3 shows specifications with alternative fixed effects and regional macro controls to assess the robustness of the identified effects of regional fiscal policy and unorthodox monetary policy.

- Table 3 around here -

The three panels in Table 3 contain results for five different fixed effect specifications for each of the three interest rate components. In column (1), we specify neither district nor month fixed effects, then we add month effects in column (2) and district effects in column (3), before comparing them in column (4) against the baseline specification that includes all three vectors of fixed effects ${ }^{17}$ Finally, we substitute district fixed effects with regional macro variables at the district level in column (5). We observe the district's unemployment rate, level of gross domestic product, level of corporate tax rate, and debt level in the year the loan is issued, as well as the total loan volume the bank issued in the district in the respective week, for about $90 \%$ of firms in our sample.

\footnotetext{
${ }^{15}$ The results are robust to using clustered standard errors instead of robust standard errors, which we use in all of our analysis if not indicated otherwise.

${ }^{16}$ Analysing the flow of asset purchase programs under SMP and CBPP instead of the cumulative amount of asset purchases shows no significant effects on loan pricing. The is potentially due to the heterogenous distribution of flows over time, that is a few large amounts bought at the beginning of the programms and some smaller amounts in the following weeks.

${ }^{17}$ We also specified time-district fixed effects in addition to firm-product fixed effects to control for variation within districts and between districts over time. This analysis confirms that $U M P$ has a significantly negative effect on the refinancing rate.
} 
For the interest rate charged to customers, the results demonstrate the need to control for the cyclical effects of monetary policy. Failing to specify month fixed effects falsely assigns security purchases a loan price increasing effect. The reduction of refinancing costs also is estimated with bias when omitting these month-specific effects. Adding regional macro covariates leaves all of our main results intact. Moreover, the results alleviate the endogeneity-related concern that fiscal policy is not orthogonal to monetary policy. This might be the case if the decision to change taxes is influenced by municipalities being owners of local savings banks which are hit by the 2008 financial crisis through their head institution (see Puri et al., 2011). Then RFS would not measure changes in demand but affectedness of municipalities by the financial crisis. Our results hold when we include the district's debt level, which alleviates the concern that districts are indebted because of regional savings banks' distress and systematically choose their fiscal policy regarding corporate taxation 18 Table 3 shows that our results are robust to current debt levels of thee districts. However, unreported tests indicate a dependency of $R F S$ on lagged macroeconomic indicators, leading us to further robustness tests using intruments in the following section. Overall, our model saturated with fixed effects provides conservative estimates of the possible effects of regional fiscal policy and a common unconventional monetary policy.

\subsubsection{Instrumental variable estimation}

We use changes in fiscal policy as an exogenous shock to firms influencing their demand for loans. Therefore, we need to ensure that it is indeed the change in the corporate tax rate that affects loan demand instead of other unobserved factors that drives the change in corporate taxes. Figure 3 indicates substantial spatial dispersion of tax rates over time. And figure 5 confirms that next to average tax rates, mean macroeconomic conditions as well as average lending activity varies considerably at the regional level.

- Figure 5 around here -

West German districts exhibit high levels of corporate taxes whereas average regional output growth is more dispersed. Likewise, average loan growth is dispersed with higher mean levels in the more prosperous western regions.

Thus, the specification of regional debt and output conditions shown in Table 3 is indeed important to alleviate possible ommitted variable bias. But it is insufficient to rule out that lower

\footnotetext{
${ }^{18}$ Including the district specific Lerner index as a measure of local banking competition confirms our results.
} 
corporate tax rates as fiscal stimulus are the result rather than the cause of loan demand shifts.

Therefore, we conduct a two-stage least-squares estimation and instrument the $R F S$ by three variables that explain changes in corporate taxes well, but are arguably weakly correlated with the corporate demand for credit. First, Foremny and Riedel (2014) show that German corporate taxes are determined at the regional level systemically different dependent on whether an election is held in the municipality in question. They show that in the run-up to regional elections, tax rates are significantly more likely to be reduced. Therefore, we manually collect election results at the regional level, so called "Gemeindewahlen", from state statistical offices and public sources and specify an indicator equal to one if there is a regional election in the district in the respective year.

Second, in the spirit of, for example, Lambert et al. (2012), we use natural disasters as a random aggregate demand shock. These aggregate shocks often trigger public policy in terms of spending, tax cuts, or a combination of both. Extreme weather conditions represent unanticipated shocks that can occur within narrow regional confinements, for instance the banks of flooding rivers. The economic damage clearly depends not only on meteorological intensity of disasters, such as hailstorms or floods, but also on the economic damage inflicted. Therefore, we source data from the annual Natural Hazard Reports ("Naturgefahrenreport") provided by the German Association of Insurances. The report indicates the monetary damage covered by insurances due to storm, hail, and flooding at the district level ${ }^{19}$ The variable damages by storm is an integer ranging between 1 and 9, where larger numbers indicate higher severity.

Third, we use the rate of unemployment as an indicator of the district's economic well-being as an instrument. The main determinant of local tax policies is indeed to stimulate economically weaker regions and, in particular, employment. Since we are considering corporate loan demand, we therefore argue that unemployment should correlate well with tax policy of the local politicians, but is sufficiently weakly correlated with loan demand and thus prices, which we explain.

- Table 4 around here -

Table 4 depicts in the upper panel coefficient estimates of the instrumental variables in the first stage regression. All chosen instruments are significantly related to $R F S$, both individually as well as jointly. Both regional elections as well as storm damages increase the likelihood of a

\footnotetext{
${ }^{19}$ See, for example, www.gdv.de We are grateful for the provision of these data by the GDV.
} 
fiscal stimulus in the form of reduced corporate tax rates. Higher unemployment, in turn, reduces the likelihood of tax reductions. This result indicates that adverse economic conditions in certain regions' labor market might be tackled more likely with direct transfer payments rather than corporate tax cuts, which would further burden public finances.

For our purposes, we are more interested whether the instruments fulfill the necessary requirements, that is, whether they explain fiscal stimuli well but are uncorrelated with the three outcome variables. According tests for weak and overidentification are shown as well where applicable. All three instruments are jointly significant to explain $R F S$ well as demonstrated by the F-statistic that accounts for clustered standard errors. Likewise, the Hansen-J statistic strongly supports the (statistical) validity of our instruments as well.

Panels A through $\mathrm{C}$ depict the second stage regression results for the three different interest rates using the instrumented fiscal policy shock, IRFS. Using the preferred specification of jointly specifying all three instruments confirms all our main findings. Customer interest rates increase in response to fiscal stimuli, an effect that is mitigated by expansionary $U M P$. The instrumented regional fiscal shock, IRFS, also has a positive effect on the interest margin. Likewise, the refinancing cost of the bank decline in direct response to an expansion of $U M P$. Interestingly, when instrumenting $R F S$, the positive direct term of $U M P$ on interest margins is now contrary to the baseline also significantly different from zero.

This last result suggests that unusual expansionary monetary policy measures launched by the ECB in support of EMU periphery countries' sovereign yields not only benefited banks in terms of refinancing cost. It also provided banks with a significantly larger economic rent they earned.

\subsubsection{Multi-region and multi-firm enterprises}

As an additional check whether we identify loan demand, we exploit the feature that not all corporations in our sample are standalone enterprises. A few borrowers belong, however, to multifirm enterprises with operations in different German districts. Those firms are not only exposed to fiscal policy in the region where they are headquartered, but indirectly also by policy in districts where connected firms are located, for instance through changes in demand in internal capital markets. We therefore compare firms in districts without any fiscal policy shock that have at least one connected firm in a different district exposed to a stimulating fiscal policy shock against standalone firms in the same district. This comparison is relevant for the contagion effects of demand shocks, and it also provides a test in which fiscal policy in a distant district arguably 
should be orthogonal to firms' credit demand.

- Table 5 around here -

Instead of $R F S$, we use an indicator equal to the number of affiliated firms in a foreign district experiencing a stimulating fiscal policy shock, FRFS. Table 5 shows that firms are affected by fiscal policy shocks that do not occur in their own district but districts of their affiliates. Those firms pay a higher average interest rate on their loans than standalone firms. Unconventional monetary policy also has a diminishing effect on the interest rate in interaction with fiscal policy and reduces the refinancing component of the interest rate. We find the same direction of effects with respect to the interest margin. Although these findings move in the same direction as the effects derived from our main results, they are not significant. This lack of significance likely reflects the substantially smaller sample size, because we include only those districts without any regional fiscal policy change. In addition to confirming our main results, this finding supports our assumption that regional fiscal policy shocks are exogenous to a firm's credit demand, because the effect is in the same direction working through different firms' common internal capital market across districts.

\subsection{Type and timing of unconventional monetary policy}

\subsubsection{Separating asset purchase programs}

Thus far, we have looked at the aggregate of unconventional monetary policy measures. In Table 6. we distinguish between the cumulative amount of assets bought under the Securities Markets Programme, SMP, and the Covered Bond Purchase Programme 2, CBPP.

- Table 6 around here -

The separate specification of both programs shows that most of the effects we find to be statistically significant are driven by the $S M P$ program. Whereas we find neither direct nor interaction effects from $C B P P$, the $S M P$ confirms the baseline effects reported earlier. Customer interest rates in column (1) exhibit the same direct and interaction effects of fiscal and monetary policy measures as before. The demand stimulating fiscal shock, in combination with increasing interest rates and the interest rate decreasing effect of the $S M P$, also persist in the joint specification with $C B P P$ in column (3).

The $S M P$ has a significantly decreasing effect on the refinancing rate, both when specified separately and jointly with $C B P P$. The interest rate shifting effect of fiscal policy remains evident 
in this configuration. The results for the interest margin mimic those for the customer interest rate, as shown in the rightmost panel of table 6 Regarding customer interest rates, the effect of the $C B P P$ remains statistically insignificant throughout.

We conclude that the substantially larger $S M P$ had the significant effect on loan pricing as opposed to the smaller $C B P P$.

\subsubsection{Asset purchase programs vs. additional lending facilities to banks}

In addition to these unconventional measures, longer-term refinancing operations (LTRO) permitted banks to lend money at fixed terms for a fixed time from the ECB. Those measures, taken during the European sovereign debt crisis, also sought to foster lending and stabilize banking operations. We test for the bank's monthly usage of $L T R O$ in addition to $U M P$ to determine whether part of the effects we find are caused by LTRO. Table 7 shows the results for all interest variables and the different specifications we test.

- Table 7 around here -

We add $L T R O$ as an explanatory variable into our baseline regression and interact it with both $U M P$ and RFS. The results are in column (2), next to our baseline results in column (1). We find a negative but insignificant effect of $L T R O$ on any variable of interest, interest rate, refinancing rate, and interest margin. Nevertheless, when specifying $U M P$ together with $L T R O$, our baseline findings hold. The $U M P$ has a significant negative effect on the refinancing rate and a reducing effect on interest rates and interest margins in interaction with fiscal policy. A demand-stimulating fiscal policy shock increases interest rates and the interest margins. Thus, our baseline results are confirmed, albeit with lower significance. Evidence from this analysis suggests it is not LTRO that drives the effect but $U M P$.

The asset purchase programs in particular targeted assets from EMU periphery countries: Portugal, Ireland, Italy, Greece, and Spain. Therefore, the effects we look at should be sensitive to the amount of respective assets the bank holds in its portfolio. We collect this information from quarterly balance sheet reports and weight the amount of $U M P$ with the ratio of assets from

periphery countries over total assets. As reported in column (3), the effects remain intact and significant when we use $U M P_{-} P A$ instead of $U M P$.

Thus, unconventional asset purchase programs had an effect on credit pricing above and beyond additional liquidity provision schemes, such as $L T R O$. 


\subsubsection{Words or deeds: Draghi's London speech}

According to Ferrando et al. (2015), the speech by ECB President Mario Draghi in London in August 2012 was a hallmark in restoring faith with financial markets participants. Table 8 shows the estimation results when we divide the sample into subsamples, before and after this speech.

-Table 8

The effects for the three interest rates persist in the period after August 2012. Fiscal policy that stimulated credit demand increased both customer interest rates and the margins earned by the bank, and $U M P$ mitigated this effect. The direct effect of the latter policy on reducing refinancing rates also was significant after the Draghi speech, though at a lower level of significance, which may reflect the reduced power of our tests given a smaller sample. A reduced sample size may also explain why we find mostly consistent coefficients prior to August 2012, which are however insignificant. An exception is the large positive coefficient estimated for the direct $U M P$ effect on margins prior to August 2012.

\subsection{Firm heterogeneity}

\subsubsection{Financially constrained firms}

Firms that are financially constrained might behave differently with respect to loan demand and experience differences in loan pricing. To control for firm heterogeneity with respect to credit constraints, we investigate balance sheet information of the firms. The bank collects the balance sheet data, because firms must report this information during the loan granting process and for monitoring activities. Yet we do not have balance sheet information for all firms, so we avoid using the balance sheet information explicitly as explanatory variables in our main regressions. Nevertheless, this information is incorporated indirectly through the firm's rating, which takes into account a financial analysis of the firm. We use the balance sheet data to test the effect of firms' cash-flow, which Almeida and Campello (2007) propose as an indicator of constraint, on loan pricing. We also use the balance sheet data to divide firms into those that are most versus least constrained, to determine if this drives our main results with respect to the interest rate. Table 9 shows our findings.

- Table 9 around here -

For nearly $60 \%$ of firms, we observe their gross cash-flow rate. Column (2) shows our baseline result, with cash-flow over total assets as an additional explanatory variable. Cash-flow significantly 
reduces the interest rate paid by a firm. Although firms that rely more on cash are supposed to be constrained in their financing, more cash at hand reduces the cost of financing. By interacting cash-flow with monetary and fiscal policy, we find that in interaction with an $U M P$ more cash-flow increases the interest paid. In other words, the more financially constrained firms are, the more they pay interest for their loan, given that an $U M P$ is in place. Our baseline findings hold in this specification.

In columns (3)-(6), we divide firms into the most and least financially constrained, using two measures. The first is the indicator proposed by Whited and $\mathrm{Wu}(2006)$. Although we find a negative relationship between cash-flow and the interest rate for unconstrained firms and a positive one for constrained firms, suggesting that cash-flow is valued positively by firms with financing alternatives, these results are not significant. The lack of data for all firms might drive this phenomenon. Our baseline findings hold for firms classified as financially unconstrained. In our opinion, this indication suggests that unconstrained firms are more sensitive in their investment behavior following a regional fiscal stimulus than are financially constrained firms. This finding holds if we use firms' average asset size between 2011 and 2013 as a measure of constrainedness. We classify the lowest tercile of firms as those that are most constrained, due to their greater opacity and higher informational asymmetries between the firm and the bank. The largest firms are classified as the least constrained. Our baseline findings hold for the latter type of firms, for which we also find a significant negative relationship between cash-flow and pricing. However, having $U M P$ in place counteracts the reducing effect of cash-flow and increases the interest rate significantly.

Overall, financial constraint matters for loan pricing and $U M P$ reduces the interest rates in particular for unconstrained firms.

\subsubsection{Customer segments: size, firm age, relationship duration}

A further dimension we investigate in unreported test concerns customer heterogeneity. The bank segments customers into small, medium, and large SMEs. Small customers tend to be different due to their high degree of opacity. We test whether the effects of the UMP and regional fiscal stimulus differ in subsamples comprised of distinct customer segments. We confirm the baseline effects on loan pricing for medium and large customers. It may be that larger firms are more sensitive to changes in corporate taxes and react to stimulating events by increasing investments, whereas small firms' investment demand is more inelastic with respect to fiscal policy. 
Next, we distinguish borrowers according to their age. We use the 25th and 75th percentiles of the age distribution as our reference points to differentiate young, medium, and old firm samples. Stimulating fiscal shocks go along with an increase in interest rates only for young and old firms. For those firms, we also find a significant interaction effect of monetary and fiscal policy. Thus, our results indicate that firms differ with respect to their sensitivity to fiscal policy changes if they belong to one of the extremes of the age distribution for firms.

Finally, we explore subsamples according to the length of the bank-customer relationship. We use again the 25th and 75 th percentiles of the distribution of the variable "length of customer relationship" to build subsamples of short, medium, and long relationships. By and large, we find no significant effects across these subsamples.

\subsection{Loan product peculiarities}

\subsubsection{New lending versus extensions at different terms}

Monetary and fiscal policy shocks should only affect new credit decisions, not outstanding stocks of loans. Whereas in general we consider only those loans that feature new conditions, we further separate loans that are completely new business from rolled-over credit with existing customers at new conditions in Table 10 .

- Table 10 around here -

As Table 10 shows, the effect of monetary and fiscal policy on the interest rate is the same, regardless of whether it is a new or prolonged loan. The same finding occurs with respect to the interest margin, in that a stimulating fiscal policy has an increasing effect on the interest rate, and the interaction with the $U M P$ acts to alleviate higher interest rates. Unconventional monetary policy reduces refinancing costs only for new loans. One reason might be that the refinancing conditions are fixed for a longer period than the interest margin, so the refinancing rate of prolonged loans is not sensitive to current market conditions.

\subsubsection{Credit product categories}

The sample of loans we observed can be divided into four different loan categories. Money market loans have a maturity of at most one year and a fixed interest rate. They tend to be used to finance working capital. Promotional bank loans are originated by a government or supranational institution, such as development banks, which cover the refinancing for commercial banks that 
distribute these loans to their corporate customers, provide advice, and determine the complete credit pricing. Next, investment loans have medium or long durations. Finally, we observe leasing. The latter three credit categories are of a longer-term nature and therefore tend to finance investments. Given their different nature and maturity, we investigate in Table 11 whether different loan categories, depicted in panel A through $\mathrm{D}$, respond differently to fiscal and monetary policy.

- Table 11 around here -

We apply our baseline identification to each of the loan categories to identify whether different loan products are affected differently. The effect of stimulating fiscal policy and its interaction with unconventional monetary policy measures on loan pricing is driven by the largest group of money market loans. However, the effect on the refinancing rate turns insignificant. For the remaining three categories, we estimate coefficients that exhibit, for the most part, similar directions to those we uncovered in the baseline model, though they are not statistically discernible from zero. From these findings, we conclude that especially short-term loans that suit the funding demand for working capital are significantly sensitive to positive fiscal policy shocks and parallel fiscal and monetary policy shocks.

\section{Conclusion}

We use a proprietary loan pricing data set from a large bank in Germany to analyze the intrabank transmission of unconventional monetary policy $(U M P)$. For a sample of 40,116 observed loans to corporate borrowers, we test the effect of security purchases by the European Central Bank, under the Security Markets Program and the Covered Bonds Purchase Program, on customer interest rates, interest margins earned by the bank, and refinancing rates between August 2011 and December 2013.

To identify the effects of the enhanced credit supply due to $U M P$, we rely on the regional corporate tax shocks to which individual firms are exposed. These fiscal shocks control for demand, thereby creating a quasi-experimental setting where we can identify how a euro area wide monetary policy, set at the European level, interacts with local fiscal policy that is determined autonomously at the district level.

Security purchases by the ECB reduced the funding cost of banks significantly. But we find no direct effect of unconventional monetary policy on a borrower's loan interest rate or margins earned by the bank. Thus, expansionary monetary policy aimed to alleviate funding pressure in 
particular on sovereign debt of the periphery of Eurozone members did not reduce overall cost of credit in other parts of the Eurozone.

Regarding regional fiscal policy, we find that customers that reside in districts that lowered their corporate tax rates pay approximately $0.45 \%$ higher loan rates, consistent with greater loan demand in response to a fiscal stimulus. This result indicates that a decentralized fiscal policy, for instance in an attempt to stimulate aggregate demand and economic growth, might spark interest rates hikes. But the interaction between fiscal and monetary policy has a negative effect on the interest rates paid by corporate customers and the interest margins earned by the bank. Credit cost hikes due to fiscal impulses can thus be accommodated by an expansionary unconventional monetary policy. The overall effect on loan rates paid by our sample of German firms that dependent on bank-finance is in fact negative.

Our results are robust to the identification of loan demand with an instrumental variable approach and also remain intact also after controlling for alternative long-term liquidity provisioning by the ECB and the actual exposure of the bank to sovereign debt in the periphery of the Eurozone. The much larger security market purchase program drives the estimated effect whereas the much smaller (second) covered bonds purchase program exhibits limited effects. We conclude that large sizeable purchase programs might be needed to exert significant effects on loan terms. In addition, we find that the effects are most pronounced after the speech of the ECB's president corroborating the commitment of the central bank to do whatever it takes to restore faith in the currency. This result underpins that words remain at least as important as deeds in easing credit terms in the Eurozone. 


\section{References}

Acharya, V., I. Drechsler, and P. Schnabl (2014). A pyrrhic victory? Bank bailouts and sovereign credit risk. The Journal of Finance 69, 2689-2739.

Acharya, V. and S. Steffen (2015). The "greatest" carry trade ever? Understanding Eurozone bank risks. Journal of Financial Economics 115, 215-236.

Acharya, V. V. and O. Merrouche (2013). Precautionary hoarding of liquidity and inter-bank markets: Evidence from the sub-prime crisis. Review of Finance 17, 107-160.

Adam, K. and R. Billi (2007). Discretionary monetary policy and the zero lower bound on nominal interest rates. Journal of Monetary Economics 54, 728-752.

Adam, K. and R. Billi (2014). Distortionary fiscal policy and monetary policy goals. Applied Economics 122, 1-6.

Almeida, H. and M. Campello (2007). Financial constraints, asset tangibility, and corporate investment. Review of Financial Studies 20, 1429-1460.

Angeloni, I. and E. Faia (2013). Capital regulation and monetary policy with fragile banks. Journal of Monetary Economics 60, 311-324.

Araújo, A., S. Schommer, and M. Woodford (2015). Conventional and unconventional monetary policy with endogenous collateral constraints. American Economic Journal: Macroeconomics 7, $1-43$.

Benmelech, E. and N. K. Bergman (2012). Credit traps. American Economic Review 102, 30043032 .

Bernanke, B. and A. Blinder (1988). Credit, money, and aggregate demand. American Economic Review 78, 435-439.

Bernanke, B. S. and M. Gertler (1992). The federal funds rate and the channels of monetary transmission. American Economic Review 82, 901-921.

Bernanke, B. S. and M. Gertler (1995). Inside the black box: The credit channel of monetary policy transmission. Journal of Economic Perspectives 9, 27-48.

Committee on the Global Financial System (2011). The impact of sovereign credit risk on bank funding conditions. Bank for International Settlements, CGFS Papers July 2011.

Correia, I., E. Farhi, J. P. Nicolini, and P. Teles (2013). Unconventional fiscal policy at the zero bound. American Economic Review 103, 1172-1211.

Cremers, K., R. Huang, and Z. Sautner (2011). Internal capital markets and corporate politics in a banking group. Review of Financial Studies 24, 358-401.

De Haas, R. and N. Van Horen (2013). Running for the exit: International bank lending during a financial crisis. Review of Financial Studies 26, 244-285.

De Pooter, M., R. Martin, and S. Pruitt (2012). The effects of official bond market intervention in Europe. Federal Reserve Board of Governors mimeo.

Djankov, S., T. Ganser, C. McLiesh, R. Ramalho, and A. Shleifer (2010). The effect of corporate taxes on investment and entrepreneurship. American Economic Journal: Macroeconomics 2, $31-64$. 
Doran, D., P. Dunne, A. Monks, and G. O'Reilly (2013). Was the Securities Markets Programme effective in stabilizing Irish sovereign yields? Bank of Ireland Research Technical Paper \%.

Draghi, M. (2012, July). Speech at the Global Investment Conference in London.

Drechsler, I., A. Savov, and P. Schnabl (2014). A model of monetary policy and risk premia. NBER Working Paper 20141, 1-52.

Eser, F. and B. Schwaab (2015). Evaluating the impact of unconventional monetary policy measures: Empirical evidence from the ECB's Securities Markets Programme. Journal of Financial Economics (forthcoming).

Falagiarda, M. and S. Reitz (2015). Announcements of ECB unconventional programs: Implications for the sovereign spreads of stressed euro area countries. Journal of International Money and Finance 53, 276-295.

Ferrando, A., A. Popov, and G. F. Udell (2015). Sovereign stress, non-conventional monetary policy, and SME access to finance. European Central Bank Working Paper Series No. 1820, $1-60$.

Foremny, D. and N. Riedel (2014). Business taxes and the electoral cycle. Journal of Public Economics 115, 48-61.

Fratzscher, M. and M. Rieth (2015). Monetary policy, bank bailouts and the sovereign-bank risk nexus in the euro area. Centre for Economic Policy Research Working Paper 10370.

Gambacorta, L., B. Hofmann, and G. Peersman (2014). The effectiveness of unconventional monetary policy at the zero lower bound: A cross-country analysis. Journal of Money, Credit and Banking 46, 615-642.

Gertler, M. and P. Karadi (2011). A model of unconventional monetary policy. Journal of Monetary Economics 58, 17-34.

Gertler, M. and P. Karadi (2015). Monetary policy surprises, credit costs, and economic activity. American Economic Journal: Macroeconomics 7, 44-76.

Gertler, M. and N. Kiyotaki (2010). Financial intermediation and credit policy in business cycle analysis. Handbook of Monetary Economics 1, 547-599.

Ghysels, E., J. Idier, S. Manganelli, and O. Vergote (2014). A high frequency assessment of the ECB Securities Markets Programme. European Central Bank Working Paper Series 1642.

Gilchrist, S., D. López-Salido, and E. Zakrajśek (2015). Monetary policy and real borrowing costs at the zero lower bound. American Economic Journal: Macroeconomics 7, 77-109.

Günter, C. and V. Wieland (2003). The zero-interest-rate bound and the role of the exchange rate for monetary policy in Japan. Journal of Monetary Economics 50, 1071-1101.

Heider, F. and A. Ljungqvist (2015). As certain as debt and taxes: Estimating the tax sensitivity of leverage from state tax changes. Journal of Financial Economics, forthcoming.

Ho, T. and A. Saunder (1981). The determinants of bank interest margins: Theory and empirical evidence. Journal of Fiancial and Quantitative Analysis 16, 581-600.

Iwata, S. and S. Wu (2006). Estimating monetary policy effects when interest rates are close to zero. Journal of Monetary Economics 53, 1395-1408. 
Jiménez, G., S. Ongena, J. Saurina, and J.-L. Peydró (2012). Credit supply and monetary policy: Identifying the bank balance-sheet channel with loan applications. American Economic Review 102, 2301-2326.

Jiménez, G., S. Ongena, J. Saurina, and J.-L. Peydró (2014). Hazardous times for monetary policy: What do twenty-three million bank loans say about the effects of monetary policy on credit risk? Econometrica 82, 463-505.

Kashyap, A. K. and J. C. Stein (2000). What do a million observations on banks say about the transmission of monetary policy? American Economic Review 90, 407-428.

Khwaja, A. I. and A. Mian (2008). Tracing the impact of bank liquidity shocks: Evidence from an emerging market. American Economic Review 98, 1413-1442.

Kiyotaki, N. and J. Moore (1997). Credit cycles. Journal of Political Economy 105, 211-248.

Lambert, C., F. Noth, and U. Schüwer (2012). How do banks react to increased asset risks? evidence from hurricane katrina. Goethe University Working Paper.

Lucas, A., B. Schwaab, and X. Zhang (2010). Conditional probabilities for Euro area sovereign default risk. Discussion paper No. 11-176/2/DSF29, Tinbergen Institute.

Manganelli, S. (2012, Winter). The impact of the Securities Market Programme. In Research Bulletin, Volume 17, pp. 2-5. European Central Bank.

Maudos, J. and J. Fernandez de Guevara (2004). Factors explaining the interest margin in the banking sectors of the European Union. Journal of Banking and Finance 28, 2259-2281.

Memmel, C. (2011). Banks' exposure to interest rate risk, their earnings from term transformation, and the dynamics of the term structure. Journal of Banking and Finance 35, 282-289.

Nakamura, E. and J. Steinsson (2014). Fiscal stimulus in a monetary union: Evidence from US regions. American Economic Review 104, 753-792.

Pelizzon, L., M. Subrahmanyam, D. Tomio, and J. Uno (2015). Sovereign credit risk, liquidity, and ECB intervention: Deus ex machina? SAFE Working Paper No. 95.

Puri, M., J. Rocholl, and S. Steffen (2011). Global retail lending in the aftermath of the US financial crisis: Distinguishing between supply and demand effects. Journal of Financial Economics 100, $556-578$.

Saunders, A. and L. Schumacher (2000). The determinants of bank interest rate margins: an international study. Journal of International Money and Finance 19, 813-832.

Statistische Ämter des Bundes und der Länder (2014). Ergebnisse der Steuerstatistiken. Wiesbaden: Statistisches Bundesamt.

Statistisches Bundesamt Deutschland / Regionaldatenbank Deutschland (2014, November). Realsteuervergleich. Statistic 71231 "Realsteuervergleich"; Table 356-11-4 "Realsteuervergleich Jahressumme - regionale Tiefe: Kreise und krfr. Städte".

Whited, T. and G. Wu (2006). Financial constraints risk. The Review of Financial Studies 19, $531-559$. 


\section{Appendix A Figures}

Figure 1: Tax level dispersion over time and districts

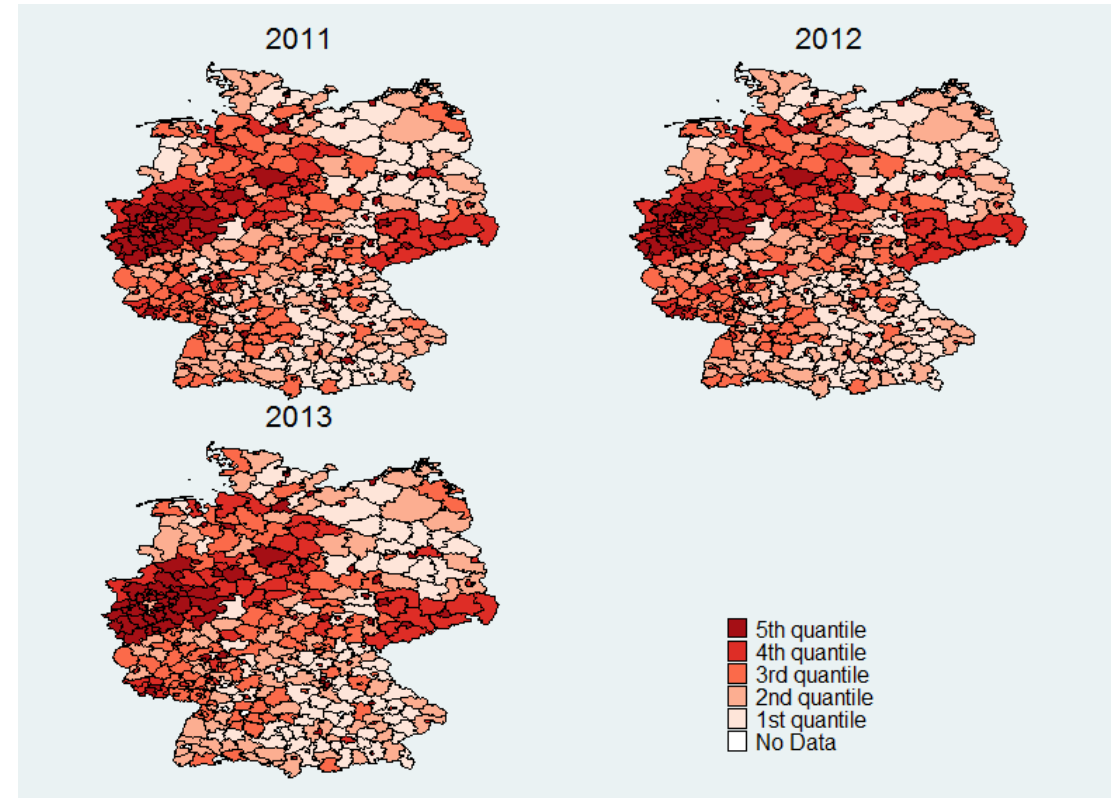

Notes: The quantiles for the levels of the tax multipliers, the corporate tax level, are as follows: 2011: 246-343-364-410445-490; 2012: 237-344-365-410-450-520 and for 2013: 223-344-365-410-450-520. 
Figure 2: Cumulative stock of purchased assets under the SMP and CBBP over time

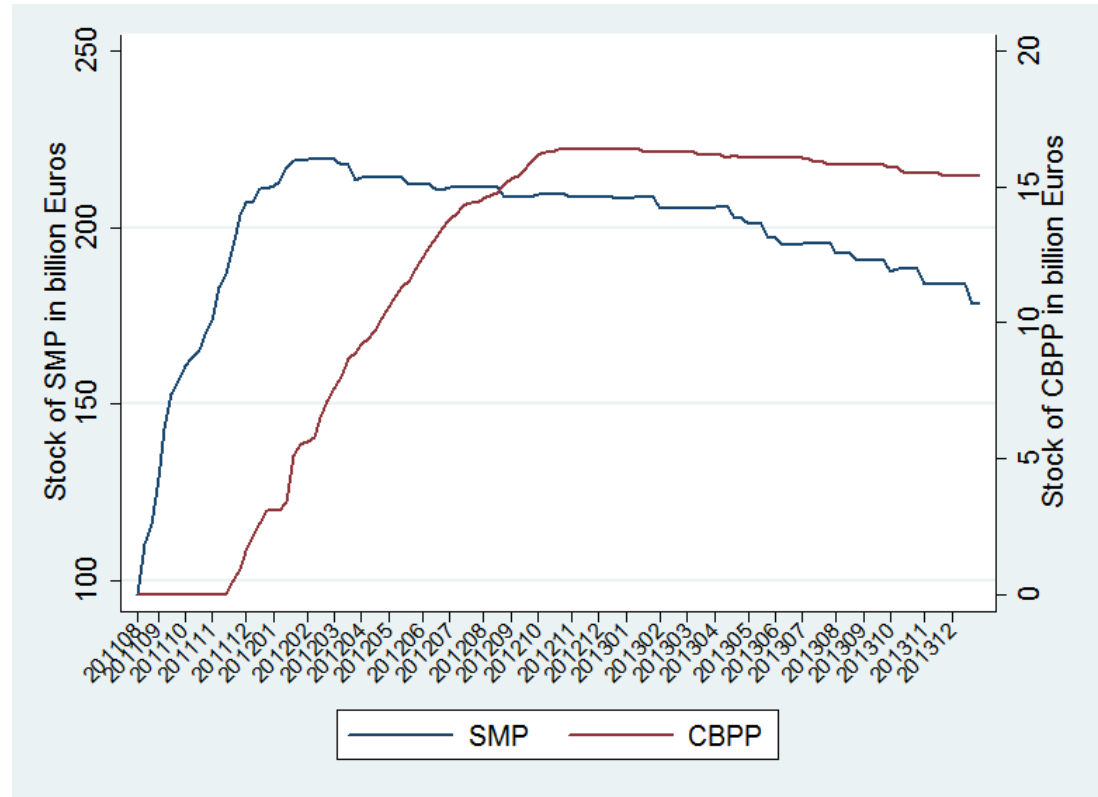

Notes: Purchased volumes in billions of Euro for Securities Markets Programme $(S M P)$ on the left axis and the Covered Bond Purchase Programme $(C B P P)$ on the right axis. Source: European Central Bank.

Figure 3: Fiscal policy over time and districts

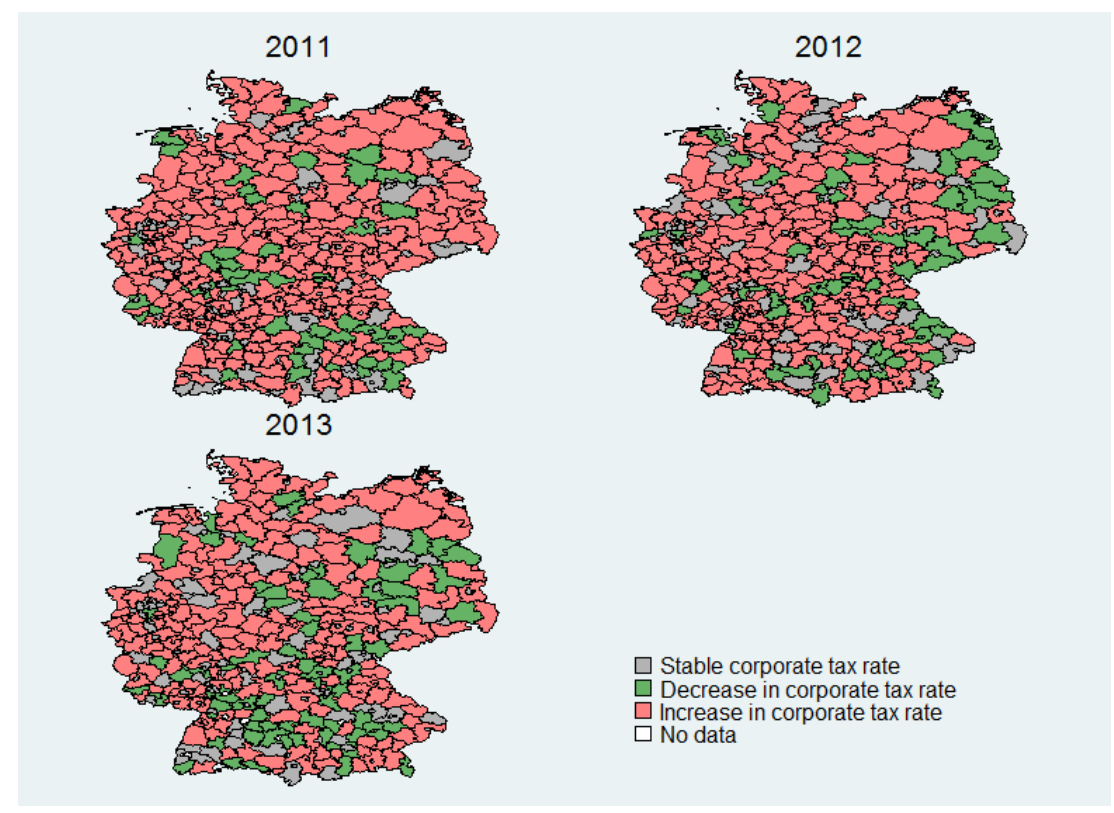

Notes: Dispersion over time whether districts lowered their corporate tax rate inducing a regional fiscal stimulus, $R F S$, increased their tax rate thereby creating a regional fiscal dampening effect, $R F D$, or kept their corporate tax rate stable relative to the previous year. Source: Statistisches Bundesamt Deutschland / Regionaldatenbank Deutschland (2014). 
Figure 4: Interest rate and its components over time

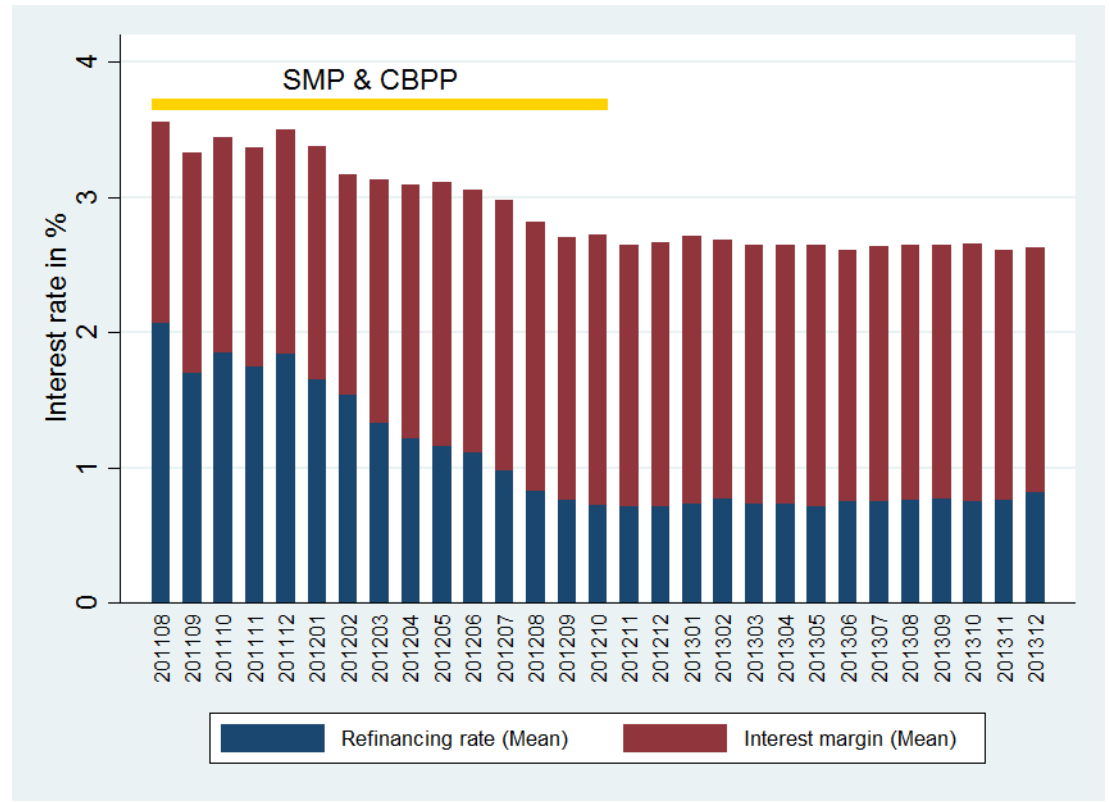

Notes: Monthly average refinancing rate and interest margin, both adding up to the interest rate. Source: data providing bank.

Figure 5: Regional macroeconomic indicators and loan volume

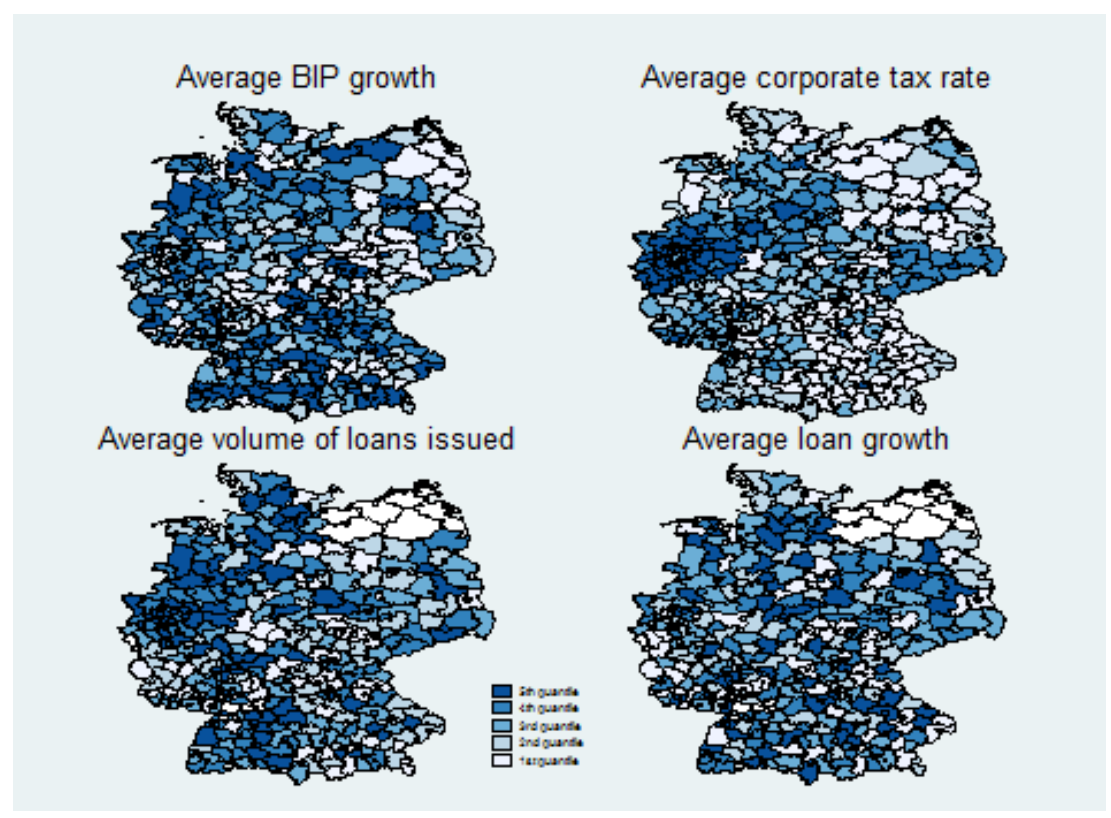

Notes: Average yearly growth rate of $G D P$, dispersion of average corporate tax level, average yearly sum of district loan volume, and average growth of district loan volume, over the complete observation period. Source: Statistisches Bundesamt Deutschland / Regionaldatenbank Deutschland (2014) and data providing bank. 
Appendix B Tables main body 
Table 1: Summary statistics and differences in mean

This table reports the number of observations, means, standard deviations and values at the 1st and 99th percentiles for all observed loans in the period between August 2011 and December 2013. For the variables of interest, the interest rate and its components, as well as the variables which explain the interest rate and its components as control variables we report the difference in means between firms treated by a regional fiscal policy shock, $R F S$, and those which experience no shock before and after outright monetary transactions, $O M T$, were announced. The last column reports the difference-in-differences of the means of both treatment groups over time. Standard errors in parentheses. $* * * \mathrm{p}<0.01,{ }^{* *} \mathrm{p}<0.05,{ }^{*} \mathrm{p}<0.1$.

\begin{tabular}{|c|c|c|c|c|c|c|c|c|}
\hline \multirow[t]{2}{*}{ Variable } & \multirow[t]{2}{*}{ Observations } & \multirow[t]{2}{*}{ Mean } & \multirow[t]{2}{*}{ Std. Dev. } & \multicolumn{2}{|c|}{ Percentiles } & \multirow{2}{*}{$\begin{array}{r}\Delta_{R F S} \\
\text { before OMT } \\
\end{array}$} & \multirow{2}{*}{$\begin{array}{r}\Delta_{R F S} \\
\text { after OMT } \\
\end{array}$} & \multirow[t]{2}{*}{$\Delta \Delta$} \\
\hline & & & & $1^{\text {st }}$ & $99^{t h}$ & & & \\
\hline \multicolumn{9}{|l|}{ Interest rates } \\
\hline Interest rate & 40,116 & 2.781 & 1.236 & 0.810 & 6.500 & $0.086^{* *}$ & -0.004 & $-0.090^{*}$ \\
\hline Interest margin & 40,116 & 1.894 & 1.216 & 0.015 & 5.561 & $0.090 * *$ & 0.008 & $-0.082^{*}$ \\
\hline Refinancing rate & 40,116 & 0.865 & 0.392 & 0.194 & 2.311 & -0.001 & $-0.010^{* *}$ & -0.009 \\
\hline \multicolumn{9}{|l|}{ Facility level $j$ controls } \\
\hline Risk-weighted assets & 40,116 & 0.907 & 2.355 & 0.000 & 9.864 & -0.059 & $-0.077^{* *}$ & -0.019 \\
\hline Collateral & 40,116 & 0.228 & 0.420 & 0 & 1 & $0.027^{*}$ & $-0.021^{* * *}$ & $-0.048^{* * *}$ \\
\hline Duration & 40,116 & 15.830 & 28.770 & 1 & 122 & 1.015 & $-0.919^{* *}$ & $-1.934^{*}$ \\
\hline Standardized & 40,116 & 0.462 & 0.499 & 0 & 1 & 0.028 & $-0.032 * * *$ & $-0.060 * * *$ \\
\hline Short-term rate & 40,116 & 0.354 & 0.327 & 0.183 & 1.557 & $-0.033^{* * *}$ & 0.000 & $0.033^{* * *}$ \\
\hline Short-term spread & 40,116 & 0.211 & 0.202 & 0.095 & 0.968 & $-0.022^{* * *}$ & $-0.003^{*}$ & $0.019 * * *$ \\
\hline \multicolumn{9}{|l|}{ Firm level $i$ controls } \\
\hline Rating & 40,116 & 6.098 & 1.586 & 3.2 & 12.4 & 0.054 & 0.038 & -0.016 \\
\hline Capital lockup & 40,116 & 25.5 & $1,392.7$ & -350.7 & 597.4 & -27.6 & -3.1 & 24.4 \\
\hline Crosssell & 40,116 & 0.992 & 0.092 & 1 & 1 & 0.004 & -0.002 & $-0.006^{*}$ \\
\hline Turnover large & 40,116 & 0.480 & 0.500 & 0 & 1 & -0.012 & 0.001 & 0.013 \\
\hline Profitable & 40,116 & 0.828 & 0.377 & 0 & 1 & 0.017 & -0.005 & -0.022 \\
\hline Profit & 40,116 & 2.953 & 38.765 & -11.523 & 52.335 & -2.177 & -0.369 & 1.808 \\
\hline $\mathrm{CF}$ & 22,118 & 0.909 & 4.415 & -4.203 & 11.038 & & & \\
\hline \multicolumn{9}{|c|}{ District level $d$ controls } \\
\hline Unemployment & 36,438 & 6.515 & 2.842 & 2.4 & 13.8 & & & \\
\hline GDP & 36,438 & 10.903 & 10.653 & 1.580 & 55.028 & & & \\
\hline District debt level & 35,729 & 0.526 & 0.660 & 0 & 2.814 & & & \\
\hline District loan volume & 40,116 & 0.011 & 0.040 & 0.000 & 0.157 & & & \\
\hline Election & 39,833 & 0.045 & 0.207 & 0 & 1 & & & \\
\hline Damages by storm & 40,116 & 1.402 & 1.851 & 0 & 8 & & & \\
\hline \multicolumn{9}{|c|}{ Unorthodox monetary policy over time } \\
\hline UMP & 40,116 & 0.215 & 0.015 & 0.161 & 0.226 & & & \\
\hline SMP & 40,116 & 0.200 & 0.014 & 0.161 & 0.219 & & & \\
\hline CBPP & 40,116 & 0.015 & 0.004 & 0.000 & 0.016 & & & \\
\hline LTRO & 40,116 & 36.482 & 27.618 & 8.419 & 76.967 & & & \\
\hline 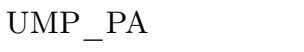 & 40,116 & 0.011 & 0.001 & 0.008 & 0.011 & & & \\
\hline \multicolumn{9}{|c|}{ Fiscal policy stance per district } \\
\hline RFS & 40,116 & 0.177 & 0.381 & 0 & 1 & & & \\
\hline RFD & 40,116 & 0.443 & 0.497 & 0 & 1 & & & \\
\hline RTC & 39,833 & 0.005 & 0.021 & -0.070 & 0.066 & & & \\
\hline Corporate tax level & 39,833 & 0.393 & 0.547 & 0.279 & 0.490 & & & \\
\hline FRFS & 40,116 & 0.040 & 0.251 & 0 & 1 & & & \\
\hline
\end{tabular}


Table 2: Unconventional monetary policy, regional fiscal policy shocks, and loan pricing Notes: We regress the interest rate, the refinancing rate, and the interest margin on the full set of variables in Table 13 , an indicator for a stimulating regional fiscal policy shock $R F S$, the accumulated stock of unconventional monetary policy $U M P$, and the interaction effect of the two. We apply an ordinary least squares regression with fixed effects for the firm-product combination, month, and district including robust standard errors. The analysis incorporates all loans between August 2011 and December 2013. Robust standard errors in parentheses. ${ }^{* * *} \mathrm{p}<0.01,{ }^{* *} \mathrm{p}<0.05,{ }^{*} \mathrm{p}<0.1$.

\begin{tabular}{lrrr}
\hline \hline VARIABLES & Interest rate & Refinancing rate & Interest margin \\
\hline & $0.450^{* *}$ & & \\
& $(0.187)$ & -0.011 & $\left(0.060^{* *}\right.$ \\
$U M P$ & -0.681 & $-2.992^{* *}$ & 2.014 \\
$R F S \times U M P$ & $(1.809)$ & $(1.273)$ & $(1.532)$ \\
& $-1.928^{* *}$ & 0.029 & $-1.906^{* *}$ \\
& $(0.846)$ & $(0.278)$ & $(0.900)$ \\
Constant & & & \\
& $1.960^{* * *}$ & $0.844^{* * *}$ & $1.056^{* * *}$ \\
& $(0.326)$ & $(0.196)$ & $(0.298)$ \\
Observations & & & 40,116 \\
Number of ID & 40,116 & 40,116 & 12,975 \\
R-squared overall & 12,975 & 12,975 & 0.0921 \\
R-squared within & 0.104 & 0.546 & 0.054 \\
R-squared between & 0.330 & 0.818 & 0.107 \\
Firm-product FE & 0.093 & 0.418 & YES \\
Month FE & YES & YES & YES \\
District FE & YES & YES & YES \\
Firm controls & YES & YES & YES \\
Facility controls & YES & YES & YES \\
Market controls & YES & YES & YES \\
& YES & YES & \\
\hline \hline
\end{tabular}


Table 4: Instrumenting regional fiscal stimulus

Notes: We instrument a stimulating regional fiscal policy shock $R F S$ by applying a two-stage least-squares estimation. We regress the $R F S$ on three exogenous regressors election, damages by storm, and unemployment separately in columns (1)-(3) and jointly in column (4). In the following panels A, B, and $\mathrm{C}$ we regress the interest rate, the refinancing rate, and the interest margin on the full set of variables in Table 13 , the instrumented stimulating regional fiscal policy shock IRFS, the accumulated stock of unconventional monetary policy $U M P$, and the interaction effect the non-instrumented $R F S$ and $U M P$. The regression includes fixed effects for the firm-product combination, month, and district and includes robust standard errors. The analysis incorporates all loans between August 2011 and December 2013. Robust standard errors in parentheses. ${ }^{* * *} \mathrm{p}<0.01,{ }^{* *} \mathrm{p}<0.05,{ }^{*} \mathrm{p}<0.1$.

\begin{tabular}{|c|c|c|c|c|}
\hline VARIABLES & $(1)$ & $(2)$ & $(3)$ & $(4)$ \\
\hline \multicolumn{5}{|c|}{ First stage estimation instrumenting Regional Fiscal Stimulus (IRFS) } \\
\hline \multirow{2}{*}{ Election } & $0.005^{* * *}$ & & & $0.007^{* * *}$ \\
\hline & $(0.001)$ & & & $(0.002)$ \\
\hline \multirow[t]{2}{*}{ Damages by storm } & & $0.001^{* * *}$ & & $0.001^{* * *}$ \\
\hline & & $(0.000)$ & & $(0.000)$ \\
\hline \multirow[t]{2}{*}{ Unemployment } & & & $-0.005^{* * *}$ & $-0.001^{* *}$ \\
\hline & & & $(0.001)$ & $(0.001)$ \\
\hline Hansen-J statistic & - & - & - & 19.21 \\
\hline Kleibergen-Paap F-statistic & 16.11 & 112.25 & 30.61 & 139.65 \\
\hline Observations & 31,837 & 33,025 & 29,835 & 29,835 \\
\hline \multicolumn{5}{|l|}{ Panel A) Interest rate } \\
\hline \multirow[t]{2}{*}{$I R F S$} & 4,795 & $3.027^{*}$ & $17.675^{* * *}$ & $4.250^{* * *}$ \\
\hline & $(3.660)$ & $(1.841)$ & $(4.557)$ & $(1.590)$ \\
\hline \multirow[t]{2}{*}{$U M P$} & 1.347 & 0.678 & 6.246 & 0.307 \\
\hline & $(2.508)$ & $(1.953)$ & $(4.444)$ & $(2.017)$ \\
\hline \multirow[t]{2}{*}{$R F S \times U M P$} & -21.909 & -13.792 & $-81.169^{* * *}$ & $-19.402^{* * *}$ \\
\hline & $(16.836)$ & $(8.475)$ & $(20.957)$ & $(7.310)$ \\
\hline \multicolumn{5}{|l|}{ Panel B) Refinancing rate } \\
\hline \multirow[t]{2}{*}{$I R F S$} & -0.617 & $1.490^{* *}$ & 1.136 & 0.134 \\
\hline & $(1.767)$ & $(0.593)$ & $(1.366)$ & $(0.737)$ \\
\hline \multirow[t]{2}{*}{$U M P$} & $-3.158^{*}$ & $-2.201^{* *}$ & $-2.803^{* *}$ & $-3.246^{* * *}$ \\
\hline & $(1.240)$ & $(1.071)$ & $(1.246)$ & $(1.063)$ \\
\hline \multirow[t]{2}{*}{$R F S \times U M P$} & 2.819 & $-6.879^{* *}$ & -5.249 & -0.637 \\
\hline & $(8.130)$ & $(2.728)$ & $(6.284)$ & $(3.387)$ \\
\hline \multicolumn{5}{|l|}{ Panel C) Interest margin } \\
\hline \multirow[t]{2}{*}{$I R F S$} & 5.924 & 2.060 & $15.565^{* * *}$ & $4.390^{* * *}$ \\
\hline & $(3.940)$ & $(1.851)$ & $(4.241)$ & (1.691) \\
\hline \multirow[t]{2}{*}{$U M P$} & $4.449^{*}$ & 2.863 & $8.224^{* *}$ & $3.281^{* *}$ \\
\hline & $(2.515)$ & $(1.749)$ & $(3.926)$ & (1.835) \\
\hline \multirow[t]{2}{*}{$R F S \times U M P$} & -27.086 & -9.319 & $-71.438^{* * *}$ & $-20.024^{* *}$ \\
\hline & (18.127) & $(8.519)$ & (19.504) & $(7.776)$ \\
\hline
\end{tabular}


Table 5: Unconventional monetary policy and fiscal policy shock effects through multi-region and multi-firm enterprises

Notes: We regress the interest rate, the refinancing rate, and the interest margin on the full set of variables in Table 13, an indicator for a stimulating foreign regional fiscal policy shock $F R F S$, the accumulated stock of unconventional monetary policy $U M P$, and the interaction effect of the two. FRFS equals the number of firms located in a different district that face a stimulating regional fiscal policy shock for firms that belong to an enterprise owning at least one other firm. We apply an ordinary least squares regression with fixed effects for the firm-product combination, month, and district, including robust standard errors. The analysis incorporates only loans to firms in districts in which the corporate tax rate is stable between August 2011 and December 2013. Robust standard errors in parentheses. ${ }^{* * *} \mathrm{p}<0.01,{ }^{*} * \mathrm{p}<0.05, * \mathrm{p}<0.1$.

\begin{tabular}{lrrr}
\hline \hline VARIABLES & Interest rate & Refinancing rate & Interest margin \\
\hline & & & \\
& 0.530 & -0.164 & $0.706^{*}$ \\
$U M P$ & $(0.367)$ & $(0.118)$ & $(0.364)$ \\
& -2.488 & -5.388 & 2.239 \\
$F R F S \times U M P$ & $(4.343)$ & $(4.927)$ & $(3.208)$ \\
& -2.041 & 0.622 & $-2.690^{*}$ \\
Constant & $(1.546)$ & $(0.468)$ & \\
& & & $1.530)$ \\
& $2.731^{* * *}$ & $1.539 *$ & $(0.652)$ \\
Observations & $(0.817)$ & $(0.839)$ & 9,059 \\
Number of ID & & & 2,994 \\
R-squared overall & 9,059 & 9,059 & 0.063 \\
R-squared within & 2,994 & 2,994 & 0.042 \\
R-squared between & 0.075 & 0.579 & 0.050 \\
Firm-product FE & 0.371 & 0.778 & YES \\
Month FE & 0.066 & 0.482 & YES \\
District FE & YES & YES & YES \\
Firm controls & YES & YES & YES \\
Facility controls & YES & YES & YES \\
Market controls & YES & YES & YES \\
& YES & YES & \\
\hline \hline
\end{tabular}




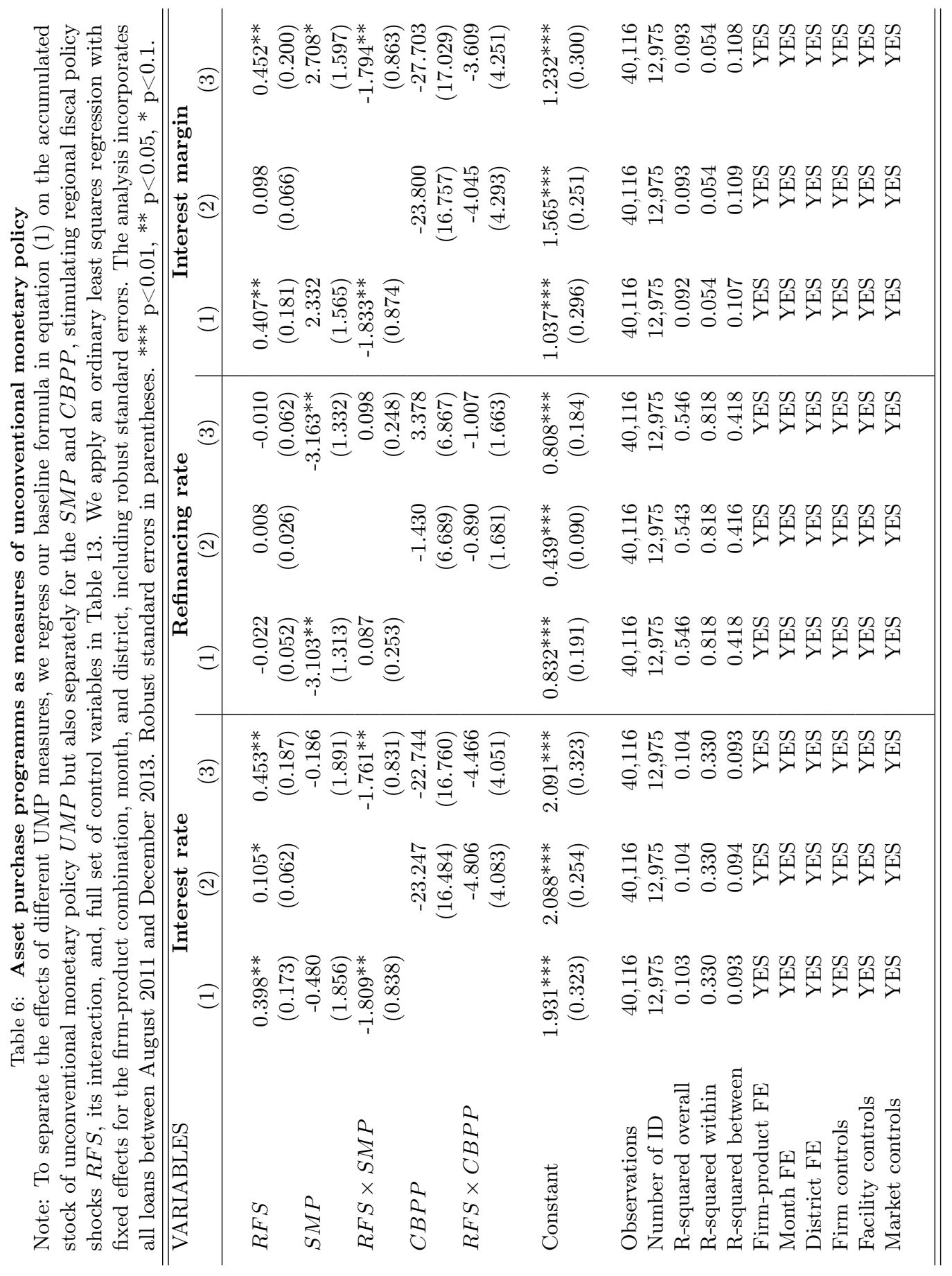




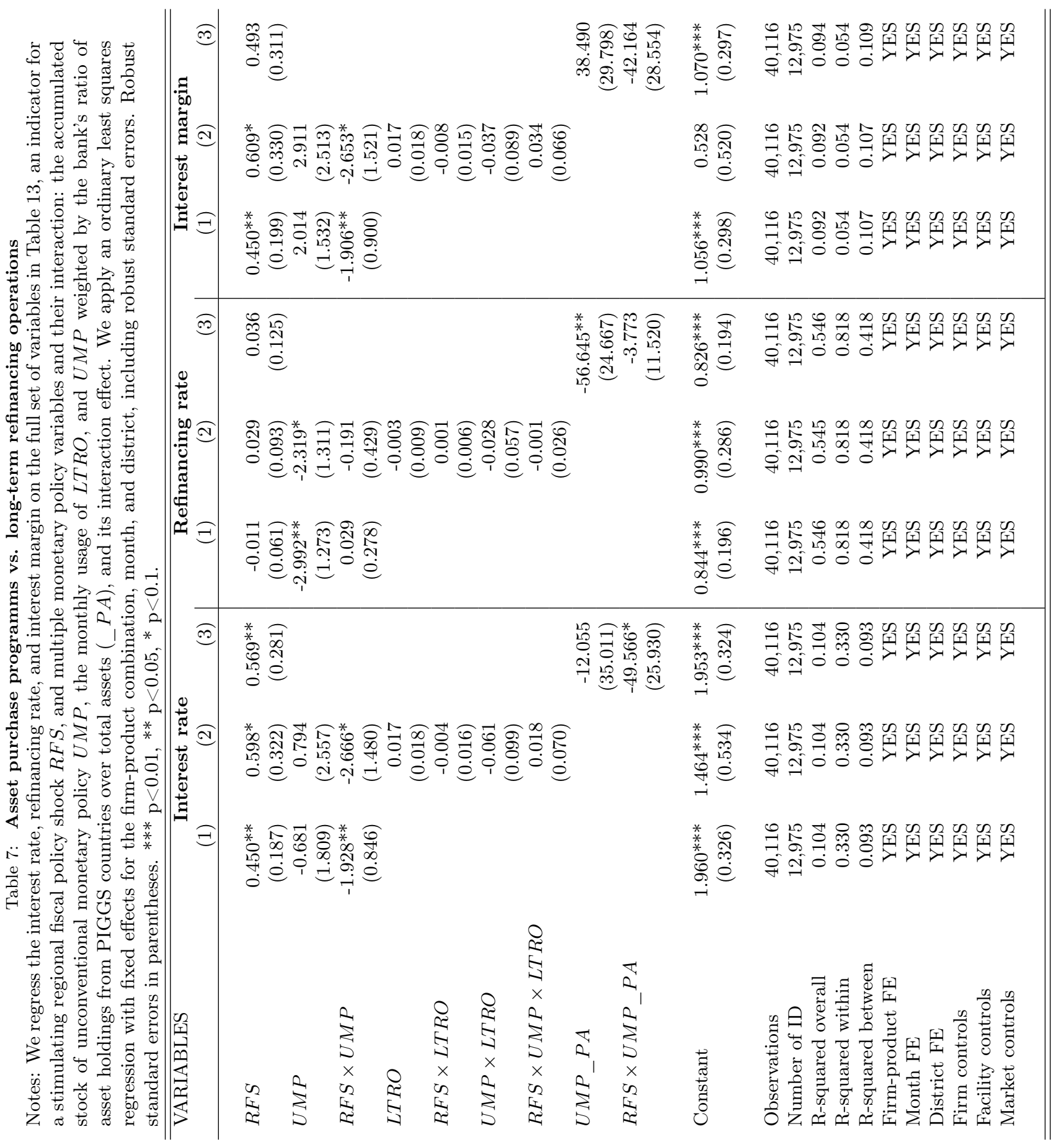


Table 8: Policy effects before and after Outright Monetary Transactions

Notes: The sample we observe is split into observations before and after outright monetary transactions (OMT) were announced in August 2012. For each period we regress the interest rate and each of its components on the full set of explanatory variables in Table 13, an indicator for a stimulating regional fiscal policy shock $R F S$, the accumulated stock of unconventional monetary policy $U M P$ and the interaction effect of the two latter policy variables. We apply an ordinary least squares regression with fixed effects for the firm-product combination, month, and district, including robust standard errors. The analysis incorporates all loans between August 2011 and December 2013. Robust standard errors in parentheses. ${ }^{* * *} \mathrm{p}<0.01,{ }^{* *} \mathrm{p}<0.05,{ }^{*} \mathrm{p}<0.1$.

\begin{tabular}{|c|c|c|c|c|c|c|}
\hline \multirow{2}{*}{$\begin{array}{l}\text { VARIABLES } \\
\text { after OMT }\end{array}$} & \multicolumn{2}{|c|}{ Interest rate } & \multicolumn{2}{|c|}{ Refinancing rate } & \multicolumn{2}{|c|}{ Interest margin } \\
\hline & 0 & 1 & 0 & 1 & 0 & 1 \\
\hline \multirow[t]{2}{*}{$R F S$} & 0.137 & $0.421^{* *}$ & -0.031 & 0.001 & 0.078 & $0.429^{* *}$ \\
\hline & $(0.447)$ & $(0.195)$ & $(0.192)$ & $(0.024)$ & $(0.457)$ & $(0.199)$ \\
\hline \multirow[t]{2}{*}{$U M P$} & 3.436 & 1.331 & -5.324 & $-0.644^{*}$ & $8.056^{* * *}$ & 1.842 \\
\hline & $(3.676)$ & $(1.670)$ & $(3.351)$ & $(0.345)$ & $(2.440)$ & $(1.696)$ \\
\hline \multirow[t]{2}{*}{$R F S \times U M P$} & -0.538 & $-1.808^{* *}$ & 0.231 & -0.015 & -0.334 & $-1.827^{* *}$ \\
\hline & $(2.088)$ & $(0.872)$ & $(0.948)$ & $(0.108)$ & $(2.141)$ & $(0.888)$ \\
\hline \multirow[t]{2}{*}{ Constant } & $1.723^{* *}$ & $1.493^{* * *}$ & $1.145^{*}$ & $0.672^{* * *}$ & 0.662 & $0.846^{* *}$ \\
\hline & $(0.775)$ & $(0.356)$ & $(0.592)$ & $(0.072)$ & $(0.527)$ & $(0.362)$ \\
\hline Observations & 7,187 & 32,929 & 7,187 & 32,929 & 7,187 & 32,929 \\
\hline Number of ID & 5,424 & 10,382 & 5,424 & 10,382 & 5,424 & 10,382 \\
\hline R-squared overall & 0.129 & 0.0589 & 0.376 & 0.179 & 0.151 & 0.102 \\
\hline R-squared within & 0.334 & 0.062 & 0.778 & 0.369 & 0.103 & 0.045 \\
\hline R-squared between & 0.115 & 0.033 & 0.332 & 0.151 & 0.164 & 0.114 \\
\hline Firm-product FE & YES & YES & YES & YES & YES & YES \\
\hline Month FE & YES & YES & YES & YES & YES & YES \\
\hline District FE & YES & YES & YES & YES & YES & YES \\
\hline Firm controls & YES & YES & YES & YES & YES & YES \\
\hline Facility controls & YES & YES & YES & YES & YES & YES \\
\hline Market controls & YES & YES & YES & YES & YES & YES \\
\hline
\end{tabular}


Table 9: Cash-flow sensitivity of interest rates and firms' credit constraints

Notes: We regress the interest rate on the full set of variables in Table 13 , an indicator for a stimulating regional fiscal policy shock $R F S$, the accumulated stock of unconventional monetary policy $U M P$, and the interaction effect of the two. Moreover, we add $C F$, or each firms' gross cash flow over total assets, as an explanatory variable. The first column corresponds to our baseline finding, as in Table 2. In column (2) the explanatory variable $C F$ is added. The subsequent columns report results for subsamples according to whether firms are more or less financially constrained. Column (3)-(4) show the results for the lowest and highest tertiles of firms with respect to the Whited $\mathrm{Wu}$ indicator, and columns (5)-(6) reveal the results for the lowest and highest tertiles of firms with respect to their average asset size between 2011 and 2013 . We apply an ordinary least squares regression with fixed effects for the firm-product combination, month, and district, including robust standard errors. Robust standard errors in parentheses. ${ }^{* * *} \mathrm{p}<0.01,{ }^{* *} \mathrm{p}<0.05,{ }^{*}$ $\mathrm{p}<0.1$.

\begin{tabular}{|c|c|c|c|c|c|c|}
\hline \multirow{3}{*}{ VARIABLES } & \multirow{3}{*}{$\begin{array}{c}(1) \\
\text { Baseline }\end{array}$} & \multirow{3}{*}{$\begin{array}{c}(2) \\
\text { Cash-Flow }\end{array}$} & $(3)$ & $(4)$ & $(5)$ & $(6)$ \\
\hline & & & \multicolumn{2}{|c|}{ Whited $\mathrm{Wu}$} & \multicolumn{2}{|c|}{ Asset size } \\
\hline & & & Constrained & Unconstrained & Constrained & Unconstrained \\
\hline \multirow[t]{2}{*}{$R F S$} & $0.448^{* *}$ & $0.504^{* *}$ & -0.179 & $1.930^{* *}$ & 0.231 & $1.606^{* *}$ \\
\hline & $(0.187)$ & $(0.237)$ & $(0.803)$ & $(0.937)$ & $(0.791)$ & $(0.702)$ \\
\hline \multirow[t]{2}{*}{$U M P$} & -0.668 & -1.276 & 12.571 & 7.182 & 0.578 & 6.156 \\
\hline & $(1.805)$ & $(2.222)$ & $(10.907)$ & $(7.097)$ & $(9.642)$ & $(7.905)$ \\
\hline \multirow[t]{2}{*}{$R F S \times U M P$} & $-1.919^{* *}$ & $-2.213^{* *}$ & 0.762 & $-8.497^{* *}$ & -0.751 & $-7.033^{* *}$ \\
\hline & $(0.847)$ & $(1.069)$ & $(3.880)$ & $(4.212)$ & $(3.669)$ & $(3.162)$ \\
\hline \multirow[t]{2}{*}{$C F$} & & $-0.086^{* *}$ & 0.104 & -0.127 & -0.229 & $-0.241^{* *}$ \\
\hline & & $(0.041)$ & $(0.205)$ & $(0.090)$ & $(0.168)$ & $(0.103)$ \\
\hline \multirow{2}{*}{$R F S \times C F$} & & 0.035 & -0.057 & -0.178 & -0.191 & 0.030 \\
\hline & & $(0.072)$ & $(0.364)$ & $(0.173)$ & $(0.300)$ & $(0.205)$ \\
\hline \multirow[t]{2}{*}{$U M P \times C F$} & & $0.361^{* *}$ & -0.594 & 0.531 & 0.976 & $1.058^{* *}$ \\
\hline & & $(0.184)$ & $(0.931)$ & $(0.405)$ & $(0.744)$ & $(0.464)$ \\
\hline \multirow[t]{2}{*}{$R F S \times U M P \times C F$} & & -0.139 & 0.484 & 0.941 & 0.893 & -0.093 \\
\hline & & $(0.328)$ & $(1.730)$ & $(0.739)$ & $(1.386)$ & $(0.917)$ \\
\hline \multirow[t]{2}{*}{ Constant } & $1.974^{* * *}$ & $1.717^{* * *}$ & $3.010^{* *}$ & -0.210 & $4.680^{* * *}$ & 0.198 \\
\hline & $(0.326)$ & $(0.510)$ & $(1.477)$ & $(1.269)$ & $(1.274)$ & $(1.357)$ \\
\hline Observations & 40,116 & 22,118 & 1,620 & 2,072 & 1,579 & 2,151 \\
\hline Number of ID & 12,975 & 7,433 & 916 & 512 & 862 & 517 \\
\hline R-squared overall & 0.108 & 0.108 & 0.031 & 0.193 & 0.028 & 0.208 \\
\hline R-squared within & 0.330 & 0.342 & 0.371 & 0.449 & 0.388 & 0.414 \\
\hline R-squared between & 0.098 & 0.095 & 0.027 & 0.133 & 0.030 & 0.135 \\
\hline Firm-product FE & YES & YES & YES & YES & YES & YES \\
\hline Month FE & YES & YES & YES & YES & YES & YES \\
\hline District FE & YES & YES & YES & YES & YES & YES \\
\hline Firm controls & YES & YES & YES & YES & YES & YES \\
\hline Facility controls & YES & YES & YES & YES & YES & YES \\
\hline Market controls & YES & YES & YES & YES & YES & YES \\
\hline
\end{tabular}


Table 10: New business versus rollover loans at new conditions

Note: We categorize each observation according to whether it is a prolonged loan for which the interest rate is newly determined or a new loan. We regress the interest rate and each of its components on the full set of explanatory variables in Table 13, an indicator for a stimulating regional fiscal policy shock $R F S$, the accumulated stock of unconventional monetary policy $U M P$, and the interaction effect of the two latter policy variables. We apply an ordinary least squares regression with fixed effects for the firm-product combination, month, and district, including robust standard errors. The analysis incorporates all loans between August 2011 and December 2013. Robust standard errors in parentheses. $* * * \mathrm{p}<0.01, * * \mathrm{p}<0.05, * \mathrm{p}<0.1$.

\begin{tabular}{lrr|rr|rr}
\hline \hline VARIABLES & \multicolumn{2}{c}{ Interest rate } & \multicolumn{2}{c}{ Refinancing rate } & \multicolumn{2}{c}{ Interest margin } \\
& Rollover & New & Rollover & New & Rollover & New \\
\hline \multirow{2}{*}{ RFS } & & & & & & \\
& $0.744^{* * *}$ & $0.617^{* *}$ & 0.019 & -0.010 & $0.725^{* * *}$ & $0.615^{*}$ \\
$U M P$ & $(0.246)$ & $(0.302)$ & $(0.015)$ & $(0.118)$ & $(0.247)$ & $(0.333)$ \\
& 2.726 & -1.358 & 0.231 & $-4.286^{* *}$ & 2.495 & 2.439 \\
$R F S \times U M P$ & $(1.671)$ & $(2.460)$ & $(0.166)$ & $(1.838)$ & $(1.677)$ & $(2.029)$ \\
& $-2.386^{* *}$ & $-2.768^{* *}$ & -0.088 & 0.023 & $-2.298^{* *}$ & $-2.733^{*}$ \\
& $(1.022)$ & $(1.400)$ & $(0.059)$ & $(0.540)$ & $(1.026)$ & $(1.534)$ \\
Constant & & & & & & \\
& $1.588^{* * *}$ & $2.139^{* * *}$ & $0.467^{* * *}$ & $0.977^{* * *}$ & $1.120 * * *$ & $1.103^{* * *}$ \\
Observations & $(0.364)$ & $(0.428)$ & $(0.042)$ & $(0.275)$ & $(0.365)$ & $(0.380)$ \\
Number of ID & 14,053 & 26,063 & 14,053 & 26,063 & 14,053 & 26,063 \\
R-squared overall & 3,717 & 12,781 & 3,717 & 12,781 & 3,717 & 12,781 \\
R-squared within & 0.048 & 0.137 & 0.308 & 0.520 & 0.052 & 0.156 \\
R-squared between & 0.038 & 0.376 & 0.397 & 0.810 & 0.034 & 0.056 \\
Month FE & 0.025 & 0.118 & 0.287 & 0.420 & 0.024 & 0.182 \\
Firm-product FE & YES & YES & YES & YES & YES & YES \\
District FE & YES & YES & YES & YES & YES & YES \\
Firm controls & YES & YES & YES & YES & YES & YES \\
Facility controls & YES & YES & YES & YES & YES & YES \\
Market controls & YES & YES & YES & YES & YES & YES \\
\hline \hline & YES & YES & YES & YES & YES & YES \\
\hline & & & & & & \\
\hline
\end{tabular}


Table 11: The effect of unconventional monetary policy and fiscal policy shocks on loan pricing for different loan product categories

Note: We perform our baseline regression for each loan product category separately. The interest rate and each of its components are regressed on the full set of explanatory variables in Table 13. an indicator for a stimulating regional fiscal policy shock $R F S$, the accumulated stock of unconventional monetary policy $U M P$, and the interaction effect of the two latter policy variables. We apply an ordinary least squares regression with fixed effects for firms, months, and districts, including robust standard errors. We performed the analysis separately for the subsamples of money market loans, promotional bank loans, investment loans, and leasing between August 2011 and December 2013. Robust standard errors in parentheses. *** $\mathrm{p}<0.01, * * \mathrm{p}<0.05, *$ $\mathrm{p}<0.1$.

\begin{tabular}{|c|c|c|c|}
\hline VARIABLES & Interest rate & Refinancing rate & Interest margin \\
\hline \multicolumn{4}{|c|}{ Panel A) Money market loans } \\
\hline \multirow[t]{2}{*}{$R F S$} & $0.433^{* *}$ & -0.017 & $0.451^{* *}$ \\
\hline & $(0.209)$ & $(0.020)$ & $(0.212)$ \\
\hline \multirow[t]{2}{*}{$U M P$} & -0.307 & -0.086 & -0.221 \\
\hline & $(1.609)$ & $(0.378)$ & $(1.618)$ \\
\hline \multirow[t]{2}{*}{$R F S \times U M P$} & $-1.878^{* *}$ & 0.063 & $-1.942^{* *}$ \\
\hline & $(0.944)$ & $(0.091)$ & $(0.957)$ \\
\hline Observations & 30,373 & 30,373 & 30,373 \\
\hline Number of firms & 5,480 & 5,480 & 5,480 \\
\hline R-squared overall & 0.129 & 0.951 & 0.100 \\
\hline \multicolumn{4}{|c|}{ Panel B) Promotional loans } \\
\hline \multirow[t]{2}{*}{$R F S$} & 0.154 & -0.127 & 0.174 \\
\hline & $(0.378)$ & $(0.176)$ & $(0.372)$ \\
\hline \multirow[t]{2}{*}{$U M P$} & 4.369 & -2.477 & 5.671 \\
\hline & $(4.452)$ & $(3.678)$ & $(3.507)$ \\
\hline \multirow[t]{2}{*}{$R F S \times U M P$} & -0.477 & 0.559 & -0.575 \\
\hline & $(1.776)$ & $(0.857)$ & $(1.749)$ \\
\hline Observations & 4,514 & 4,514 & 4,514 \\
\hline Number of firms & 3,276 & 3,276 & 3,276 \\
\hline R-squared overall & 0.269 & 0.469 & 0.057 \\
\hline \multicolumn{4}{|c|}{ Panel C) Investment loans } \\
\hline \multirow[t]{2}{*}{$R F S$} & 1.082 & 0.076 & 1.122 \\
\hline & $(1.101)$ & $(0.563)$ & $(1.477)$ \\
\hline \multirow[t]{2}{*}{$U M P$} & -7.592 & -9.556 & 2.004 \\
\hline & $(9.858)$ & $(6.016)$ & $(8.100)$ \\
\hline \multirow[t]{2}{*}{$R F S \times U M P$} & -4.230 & -0.694 & -3.950 \\
\hline & $(5.071)$ & $(2.551)$ & $(6.687)$ \\
\hline Observations & 4,306 & 4,306 & 4,306 \\
\hline Number of firms & 3,596 & 3,596 & 3,596 \\
\hline R-squared overall & 0.078 & 0.479 & 0.100 \\
\hline \multicolumn{4}{|l|}{ Panel D) Leasing } \\
\hline \multirow[t]{2}{*}{$R F S$} & 0.390 & -0.257 & 0.647 \\
\hline & $(0.923)$ & $(0.305)$ & $(0.895)$ \\
\hline \multirow[t]{2}{*}{$U M P$} & 8.356 & 7.363 & 0.993 \\
\hline & $(13.958)$ & $(4.802)$ & $(13.351)$ \\
\hline \multirow[t]{2}{*}{$R F S \times U M P$} & -2.518 & 1.213 & -3.732 \\
\hline & $(4.400)$ & $(1.483)$ & $(4.236)$ \\
\hline Observations & 923 & 923 & 923 \\
\hline Number of firms & 623 & 623 & 623 \\
\hline R-squared overall & 0.266 & 0.784 & 0.160 \\
\hline
\end{tabular}




\section{Appendix C Further tables}

Table 12: Definition

\begin{tabular}{|c|c|c|}
\hline Variable & Unit & Description \\
\hline \multicolumn{3}{|l|}{ Interest rates } \\
\hline Interest rate & Percent & $\begin{array}{l}\text { This variable is the interest rate charged to the cus- } \\
\text { tomer for the loan agreement. }\end{array}$ \\
\hline Interest margin & Percent & $\begin{array}{l}\text { This variable is the difference between the interest } \\
\text { rate and the refinance rate. }\end{array}$ \\
\hline Refinancing rate & Percent & $\begin{array}{l}\text { The cost of funds in the bank's internal capital mar- } \\
\text { ket, consisting of the funds transfer price (market } \\
\text { cost of cash-flow) and liquidity spread (liquidity risk } \\
\text { of refinancing). }\end{array}$ \\
\hline \multicolumn{3}{|l|}{ Facility level $j$ controls } \\
\hline Risk-weighted assets & $m €$ & $\begin{array}{l}\text { This variable is a bank calculated amount, in terms } \\
\text { of risk-weighted assets in million Euro. }\end{array}$ \\
\hline Collateral & $0 / 1$ & $\begin{array}{l}\text { Equal to } 1 \text { if the loan is backed by collateral and } 0 \text { if } \\
\text { otherwise. }\end{array}$ \\
\hline Duration & Number & $\begin{array}{l}\text { This variable is the duration of the loan, measured } \\
\text { in full months. }\end{array}$ \\
\hline Standardized & $0 / 1$ & $\begin{array}{l}\text { Equal to } 1 \text { if the loan was processed in a defined } \\
\text { simplified manner, and } 0 \text { otherwise. }\end{array}$ \\
\hline Short-term rate & Percent & $\begin{array}{l}\text { Level of the short-term interbank interest rate at the } \\
\text { time the loan starts. }\end{array}$ \\
\hline Short-term spread & Percent & $\begin{array}{l}\text { Difference between the short-term rate and very- } \\
\text { short-term rate at the time the loan starts. }\end{array}$ \\
\hline CDS & Percent & $\begin{array}{l}\text { Five-year senior credit default swap rate of the re- } \\
\text { spective financial institution observed. }\end{array}$ \\
\hline \multicolumn{3}{|l|}{ Firm level $i$ controls } \\
\hline Rating & Number & $\begin{array}{l}\text { Rating assigned to customer by the bank's internal } \\
\text { rating system, ascending with lower credit quality. }\end{array}$ \\
\hline Capital lockup & $\mathrm{k} €$ & $\begin{array}{l}\text { Amount of capital the bank holds against the cus- } \\
\text { tomer within the month in thousand Euro. }\end{array}$ \\
\hline Crosssell & $0 / 1$ & $\begin{array}{l}\text { Equal to } 1 \text { if in the respective year the company pro- } \\
\text { vided income by products other than loans. }\end{array}$ \\
\hline Turnover large & $0 / 1$ & $\begin{array}{l}\text { Equal to } 1 \text { if the turnover of the firm is above the } \\
\text { sample median, and } 0 \text { otherwise. }\end{array}$ \\
\hline Profitable & $0 / 1$ & $\begin{array}{l}\text { Equal to } 1 \text { if the bank generates profit with the cus- } \\
\text { tomer in the respective month, and } 0 \text { otherwise. }\end{array}$ \\
\hline Profit & $\mathrm{k} €$ & $\begin{array}{l}\text { Amount of profit or loss the bank generates with the } \\
\text { customer in the respective month in thousand Euro. }\end{array}$ \\
\hline $\mathrm{CF}$ & Number & $\begin{array}{l}\text { Ratio of gross cash flow over total capital stock at } \\
\text { the beginning of the period, less depreciation. }\end{array}$ \\
\hline
\end{tabular}

Continued on next page... 
Table 12 - Continued

\begin{tabular}{|c|c|c|}
\hline Variable & Unit & Description \\
\hline \multicolumn{3}{|c|}{ District level d controls } \\
\hline Unemployment & Percent & $\begin{array}{l}\text { Level of unemployment rate for the respective dis- } \\
\text { trict in the respective year. }\end{array}$ \\
\hline GDP & $\mathrm{bn} €$ & $\begin{array}{l}\text { Gross domestic product of the respective district in } \\
\text { the respective year. }\end{array}$ \\
\hline District debt level & $\mathrm{bn} €$ & $\begin{array}{l}\text { Amount of debt of the respective district in the re- } \\
\text { spective year. }\end{array}$ \\
\hline District loan volume & $\mathrm{m} €$ & $\begin{array}{l}\text { Total loan volume issued by the bank in the respec- } \\
\text { tive district in the respective week in million Euro. }\end{array}$ \\
\hline Election & $0 / 1$ & $\begin{array}{l}\text { Equal to } 1 \text { if election takes place in same year, } 0 \\
\text { otherwise. }\end{array}$ \\
\hline Damages by storm & Number & $\begin{array}{l}\text { Severity of damage by storm on scale } 1 \text { (rare) to } 9 \\
\text { (severe) }\end{array}$ \\
\hline \multicolumn{3}{|c|}{ Unorthodox monetary policy over time $t$} \\
\hline UMP & $\mathrm{T} €$ & $\begin{array}{l}\text { Weekly accumulated stock of assets bought under the } \\
\text { unconventional monetary policy measures } S M P \text { and } \\
C B P P \text { in trillion Euro. }\end{array}$ \\
\hline SMP & $\mathrm{T} €$ & $\begin{array}{l}\text { Weekly cumulative amount of assets bought under } \\
\text { the Securities Market Programme in trillion Euro. }\end{array}$ \\
\hline CBPP & $\mathrm{T} €$ & $\begin{array}{l}\text { Weekly cumulative amount of assets bought under } \\
\text { the Covered Bond Purchase Programme } 2 \text { in trillion } \\
\text { Euro. }\end{array}$ \\
\hline LTRO & $b n €$ & Monthly LTRO used by the bank in billion Euro. \\
\hline $\mathrm{UMP}_{-} \mathrm{PA}$ & $\mathrm{T} €$ & $\begin{array}{l}U M P \text { times the average quarterly ratio of exposure } \\
\text { to Portuga, Ireland, Italy, Greece, and Spain over } \\
\text { total assets. }\end{array}$ \\
\hline \multicolumn{3}{|c|}{ Fiscal policy stance per district } \\
\hline RFS & $0 / 1$ & $\begin{array}{l}\text { Regional fiscal stimulus: equal to } 1 \text { if corporate tax } \\
\text { rate in the district the company is located in is lower } \\
\text { than in previous year and } 0 \text { if similar or higher. }\end{array}$ \\
\hline RFD & $0 / 1$ & $\begin{array}{l}\text { Regional fiscal dampening: equal to } 1 \text { if corporate } \\
\text { tax rate in the district the company is located in is } \\
\text { higher than in previous year and } 0 \text { if similar or lower. }\end{array}$ \\
\hline RTC & Percent & $\begin{array}{l}\text { Relative tax change: difference between this and last } \\
\text { year's corporate tax rate divided by last year's cor- } \\
\text { porate tax rate for each district }(1=100 \%) \text {. }\end{array}$ \\
\hline Corporate tax level & Percent & $\begin{array}{l}\text { Level of corporate tax rate for the respective district } \\
\text { in the respective year }(1=100 \%) \text {. }\end{array}$ \\
\hline FRFS & Number & $\begin{array}{l}\text { Equal to the number of firms located in a differ- } \\
\text { ent district facing a stimulating regional fiscal policy } \\
\text { shock for firms that belong to an enterprise owning } \\
\text { at least one other firm, and } 0 \text { otherwise. }\end{array}$ \\
\hline
\end{tabular}


Table 13: Determinants of the interest rate and its components

For this table, we regress the interest rate and each of its components, the refinancing rate and the interest margin, on the full set of variables identifying each dependent variable's drivers. We apply an ordinary least squares regression with fixed effects for the firm-product combination, month, and district, including robust standard errors. The analysis incorporates all loans between August 2011 and December 2013. Robust standard errors in parentheses. *** $\mathrm{p}<0.01, * * \mathrm{p}<0.05,{ }^{*} \mathrm{p}<0.1$.

\begin{tabular}{|c|c|c|c|}
\hline VARIABLES & Interest rate & Refinancing rate & Interest margin \\
\hline \multirow[t]{2}{*}{ Risk-weighted assets } & $0.008^{*}$ & $-0.001^{* *}$ & $0.009 * *$ \\
\hline & $(0.004)$ & $(0.001)$ & $(0.004)$ \\
\hline \multirow[t]{2}{*}{ Collateral } & 0.012 & 0.003 & 0.012 \\
\hline & $(0.014)$ & $(0.003)$ & $(0.014)$ \\
\hline \multirow[t]{2}{*}{ Duration } & $0.004^{* * *}$ & $0.006^{* * *}$ & -0.001 \\
\hline & $(0.001)$ & $(0.001)$ & $(0.001)$ \\
\hline \multirow[t]{2}{*}{ Standardized } & $-0.044^{*}$ & 0.003 & $-0.050 * *$ \\
\hline & $(0.024)$ & $(0.006)$ & $(0.025)$ \\
\hline \multirow{2}{*}{ Short-term rate } & $0.602^{* * *}$ & $0.841^{* * *}$ & -0.235 \\
\hline & $(0.161)$ & $(0.073)$ & $(0.149)$ \\
\hline \multirow[t]{2}{*}{ Short-term spread } & $0.441^{* *}$ & 0.068 & $0.372^{* *}$ \\
\hline & $(0.208)$ & $(0.104)$ & $(0.188)$ \\
\hline \multirow[t]{2}{*}{ CDS } & -0.012 & -0.006 & -0.008 \\
\hline & $(0.021)$ & $(0.009)$ & $(0.020)$ \\
\hline \multirow[t]{2}{*}{ Rating } & $0.191^{* * *}$ & 0.000 & $0.188 * * *$ \\
\hline & $(0.016)$ & $(0.003)$ & $(0.016)$ \\
\hline \multirow[t]{2}{*}{ Capital lockup } & -0.000 & 0.000 & -0.000 \\
\hline & $(0.000)$ & $(0.000)$ & $(0.000)$ \\
\hline \multirow{2}{*}{ Crosssell } & 0.124 & $0.066^{*}$ & 0.080 \\
\hline & $(0.097)$ & $(0.039)$ & $(0.091)$ \\
\hline \multirow[t]{2}{*}{ Turnover large } & 0.029 & $-0.014^{* * *}$ & 0.043 \\
\hline & $(0.026)$ & $(0.005)$ & $(0.027)$ \\
\hline \multirow[t]{2}{*}{ Profitable } & $0.028 * * *$ & 0.004 & $0.024^{* * *}$ \\
\hline & $(0.008)$ & $(0.003)$ & $(0.008)$ \\
\hline \multirow[t]{2}{*}{ Profit } & -0.000 & 0.000 & -0.001 \\
\hline & $(0.000)$ & $(0.000)$ & $(0.000)$ \\
\hline \multirow[t]{2}{*}{ Constant } & $1.891^{* * *}$ & $0.427^{* * *}$ & $1.363^{* * *}$ \\
\hline & $(0.240)$ & $(0.086)$ & $(0.234)$ \\
\hline Observations & 40,116 & 40,116 & 40,116 \\
\hline Number of ID & 12,975 & 12,975 & 12,975 \\
\hline R-squared overall & 0.104 & 0.543 & 0.093 \\
\hline R-squared within & 0.329 & 0.818 & 0.053 \\
\hline R-squared between & 0.094 & 0.416 & 0.109 \\
\hline Firm-product FE & YES & YES & YES \\
\hline Month FE & YES & YES & YES \\
\hline District FE & YES & YES & YES \\
\hline
\end{tabular}


